\title{
BIASES IN THE DECISION-MAKING PROCESS AND POSSIBILITIES OF OVERCOMING THEM
}

\author{
Jelena Nikolic* \\ Faculty of Economics, University of Kragujevac, Kragujevac, The Republic of Serbia
}

Starting from the normative approach, a decision as the outcome of the decision-making process should represent a rational choice made by a completely informed decision-maker. With the development of the behavioral perspective of the decision-making process, certain mistakes in decision-makers' behavior have been noticed, emerging as a consequence of their limited cognitive capacities and the information asymmetry. The application of heuristics as simplified mental strategies, as well as certain deformations in decision-makers' thinking and perception, leads to the different biases that affect their attitudes and approach to problem solving. The aim of the research study is reflected in identifying the biases that most often occur in the decision-making process, as well as their causes and consequences. The qualitative methodology of the research has been applied in parallel with the relevant methods of analysis and synthesis, deduction and induction. On the basis of the conducted empirical studies, the recommendations for overcoming biases have been defined, which represents the main result of the research study. The derived conclusions with respect to the possibilities of overcoming biases can help decision-makers to improve the decision-making process in real situations.

Keywords: decision-making process, decision-makers, bounded rationality, mental strategies, biases

\section{JEL Classification: M10, D81}

\section{INTRODUCTION}

In the conditions of uncertainty, the promulgation of good decisions becomes the key factor for a company's success. The decision-making process represents a set of the activities that lead to making the final choice of one out of a set of possible actions by which the

* Correspondence to: J. Nikolic, Faculty of Economics, University of Kragujevac, Dj. Pucara 3, 34000 Kragujevac, The Republic of Serbia; e-mail: jnikolic@kg.ac.rs desired aim will be achieved (Babić, 1995, 14). Starting from the assumption that decision-makers are completely informed and perfectly rational beings, the development of the normative models of decisionmaking is the answer to the observed need to prescribe the procedures of decision-making that will enable a rational choice. However, it is observed that in real situations there are deviations in the application of the rational procedures of decision-making, and also that the behavior of decision-makers is under the 
influence of the uncontrolled factors that infringe the conditions of complete information and rationality.

In fact, research in the decision-making process in real situations implies the importance of understanding the limited cognitive capacities of decision-makers that lead to mistakes in the perspective of observing problems and negatively affect the effectiveness of decision-making (Maitland \& Sammartino, 2015). As a consequence of the limitation of cognitive capacities, decision-makers apply different heuristics as mental strategies by which they simplify problems and redefine the manner of their solving (Tiwana, Wang, Keil \& Ahluwalia, 2007). By introducing the concept of bounded rationality (Simon, 1955), researches in the field of strategic decision-making have been focused on the study of the cognitive abilities of decision-makers and their limits, as well as on the understanding of behavior of decisionmakers and the mechanisms of overcoming the observed limitation in the process of resolving complex problems (Menon, 2018). In accordance with the abovementioned, the understanding of mental strategies, as the mechanisms of simplifying the decision-making process, represents the first step in facing complex problems (Levinthal, 2011).

Starting from the understanding that decision-makers are bounded rational individuals, the subject matter of research are the biases as heuristics that influence the judgment of decision-makers and cause certain systematic mistakes in the decision-making process. The understanding of the biases that emerge as a consequence of the influence of different social and psychological factors on decision-makers represents the current research field in the area of the decisionmaking theory.

In the given context, the research is aimed at showing in which way biases affect the outcome of the decisionmaking process and the possible ways to overcome them. In accordance with the defined subject matter and the aim of the research, the starting research hypothesis is that the application of heuristics as mental strategies by which the decision-making process is simplified negatively affects the quality of a decision as the outcome of the decision-making process.
In accordance with the abovementioned, we started from the results of the empirical research carried out by different authors who had dealt with the influence of biases on the decision-making process.

On the basis of the survey of the relevant research that includes the partial studies of certain biases, the comprehensive analysis of the identified biases in the decision-making process represents an attempt to provide an answer to the observed research gap. The quality methodology was applied in the research, based on the descriptive study and interpretation of the results of the conducted analysis. For the purpose of deriving general attitudes regarding the causes of biases and the consequences of biases for the quality of the decision-making process, the methods of analysis and synthesis, deduction and induction, have been applied as the appropriate research methods of the theoretical verification of the set analysis.

The paper is structured into three mutually related unities. In the first part of the paper, the nature of the decision-making process and the bounded rationality of decision-makers are analyzed. Starting from the behavioral perspective, special attention is dedicated to researching the direct and indirect effects of bounded rationality in decision-making. The second part of the paper is dedicated to conducting research into the biases that emerge as a consequence of the limited cognitive capacities of decision-makers. The analyzed biases determine the manner in which decision-makers process the obtained information during the decision-making process, estimate the proposed alternatives and make a choice. On the basis of the comprehensive overview of empirical research in biases, in the third part of the paper special attention is given to identifying the possibilities of overcoming them for the purpose of improving the quality of the decision-making process.

\section{BOUNDED RATIONALITY IN DECISION- MAKING}

Although there are different approaches in the conceptual defining of the decision-making process, 
their mutual characteristic is that the decisionmaking process implies all of the activities of making the choice of one among the proposed options that include identifying problems, and the generation and choice of the alternative (Zlatanović \& Nikolić, 2017). In a broader sense, decision-making is observed as a set of the activities used in order to find and apply the course of action that will lead to the realization of the set aim. In a narrower sense, decision-making represents the choice of one out of a set of the considered options (Babić, 1995, 15). The essence of the decision-making process is the choice of the best decision. A good decision has to satisfy two main criteria: effectiveness and efficacy. An effective decision is that leading to the complete fulfillment of the set aim, whereas an efficient decision is that shaping all of the actions oriented towards the given aim so that the minimum of available resources are used (Howard \& Abbas, 2016, 30). A good decision emerges as a result of the correct understanding of problems and the defining of the aims, the creative development of alternatives, the objective evaluation of the alternatives and a consistent choice (Harrison, 1996). In order to define the procedures that will lead to making a good decision, the normative models of decision-making have been developed.

According to the normative models of rational choice, decision-making can be characterized as a rational, predictive and deterministic process. The behavior of decision-makers within the mentioned activities included in the decision-making process is characterized by rationality and the choice of the optimal solution. The problems that are resolved are well-structured and choice is consistent (Simon, 1959). The abovementioned characteristics are derived from the understanding that decision-makers, as the actors of the decision-making process, are ideally rational individuals who implement the comparative evaluation of alternatives and perform the choice of the optimal alternative on the basis of rational procedures and the rules of decision-making (Sklad \& Diekstra, 2014). In fact, according to the economic theory of a company, as the representative of the normative perspective of the study of the decisionmaking process, the behavior of decision-makers represents the explicit choice based on logic, deductive conclusions, whereby all the limitations arising from human nature are completely disregarded. On the basis of complete information, decision-makers make a calculation of the expected usefulness of the options, depending on the estimated probabilities of the relevant events and the usefulness of all of the possible outcomes of the analyzed options (Wang, 1996). A completely informed and rational decisionmaker chooses the option that maximizes the expected usefulness (Levinthal, 2011).

However, contrary to the theoretical assumptions of the normative approach, the complete rationality is unattainable for the following reasons: firstly, in the case of most decisions, the list of the potential consequences of each option is very long, with many unknown outcomes, which means that the idea of complete information is not real; secondly, the possibilities of different outcomes are usually unknown and in the best case can only be roughly estimated, by which the ability of decision-makers to make a rational choice is challenged; thirdly, decision-makers do not always behave compliantly with the principle of maximizing. This type of thinking, which implies the optimization, cannot resolve complex social problems since it ignores the different perceptions, values and interests present in organizations (Zlatanović, 2010). Starting from the observed limitations of the normative approach, the perspectives in the study of the decisionmaking process are changed. The rationality of decision-makers is observed through the prism of the interdependence of objective, rational behavior and the behavior conditioned by the behavioral factors that shape the perception and judgment of decision-makers (Zlatanović \& Nikolić, 2017). With the development of behavioral theory, it is observed that in real situations the behavior of decision-makers is characterized by bounded rationality, since their capacities are limited in relation to the problem that is being solved (Simon, 1959).

In fact, the behavioral perspective leads to the understanding of the fact that the behavior of the actors of the decision-making process in real situations often significantly differs from rational choice and is based on the application of the simple 
decision-making rules. These conclusions have led to the assumption about the bounded rationality of decision-makers that arises as a consequence of the problem related to the information asymmetry and the limited cognitive capacities of the actors of the decision-making process. As the founder of the concept of bounded rationality, Simon (1955) describes the limitations arising from human nature and the inability of rational decision-making. The foregoing means that the quality of decisions is determined by the degree of the limitation of the decision-maker's cognitive abilities (Huber, 1980, 25). This attitude originates from the understanding of the fact that a decision-maker can only consider a limited number of information at one moment; that he/she has to make a decision in a limited period of time, and also that a decision-maker cannot possess all of the relevant pieces of information. In the stated context, it is more difficult for decision-makers to find satisfying, not optimal solutions (Simon, 1959). Starting from the concept of bounded rationality, a conclusion can be drawn that decision-makers act on the basis of the simplified mental models shaped under the influence of personal attitudes, perceptions and biases. In fact, research in the decision-making process in real situations implies the discovery of the different perceptions or understandings of the world, as well as the manner in which these perceptions change over time and differ between the actors of the decisionmaking process (Zlatanović, 2010). It means that ambiguity, inconsistency and independence become the key characteristics of the decision-making process, which leads to the confirmation of the assumption on the bounded rationality of decision-makers.

In order to overcome the limitation of cognitive capacities, decision-makers often simplify decisionmaking, relying on the application of heuristics (De Neys, 2010). In many cases, these "mental shortcuts" lead to a rough approximation related to the optimal solution (Pavličić, 2015, 301). In accordance with the above-stated, one of the direct effects of bounded rationality is related to the attitude that in real situations decision-makers do not make the optimal choice (Campitelli \& Gobet, 2010). In fact, they use the simplified procedures and rules of decisionmaking. One such rule is the choice of the satisfying alternative, which means that the alternative that satisfies decision-makers' demands is chosen, whereas only in exceptional cases do decision-makers opt for searching for and selecting the optimal alternative (March, 1994, 18). Also, as a consequence of bounded rationality, decision-makers often make only the minimum of the incremental adjustment necessary to reduce the problem to such a degree at which the difference between the wanted and the existent aims is acceptable. Such an approach can be efficient in the short-term, but observed in the long-term, such a behavior can cause unwanted consequences.

Another direct effect of bounded rationality is the application of the inadequate models of decisionmaking. It means that, due to limited cognitive capacities, decision-makers use an approximate, simplified model of a real situation (Bresnick \& Parnell, 2013, 33). The application of such models helps decision-makers to solve complex problems through the application of the different "mental shortcuts" that enable their simplification (Levinthal, 2011; Menon, 2018). The models of decision-making based on heuristics are less efficient than the optimization models whose application in solving problems implies the collection of all of the relevant pieces of information, as well as the mathematical specification of alternatives. Contrary to that, the application of heuristics is based on "ignoring information" for the purpose of faster and simplified decision-making regarding the application of optimization methods (Maitland \& Sammartino, 2015). The application of the simple rules and inadequate models of decisionmaking as a direct consequence of the phenomenon of the bounded rationality of decision-makers leads to a decrease in the quality of a decision. The stated consequences of bounded rationality can be related to certain psychological factors that affect decisionmakers in the process of collecting and analyzing the information relevant to the decision-making process. Psychological factors, such as the ungrounded selfconfidence of decision-makers, excessive bonding to the initial information, connecting alternatives with stereotypes, giving support to wrong choices and dependence on the form of displaying problems can, to a great extent, shape the perception of decisionmakers in the decision-making process and the final 
outcome (Bresnick \& Parnell, 2013, 35). It is about the biases arising as a consequence of the cognitive limitation of decision-makers and causing the filtrated collection and subjective evaluation of information in favor of those who confirm their attitude about certain problems, ignoring the information contrary to their opinions. In accordance with the said, the influence of the information asymmetry leads to the information barriers that cause the filtrated collection of information. Under the influence of information barriers, decision-makers form their own personal preferences that can lead to a distortion in the information analysis (Jamieson \& Hyland, 2006). Also, the amount of information available to decision-makers often exceeds their cognitive abilities necessary for processing information. Due to cognitive limitations, decision-makers are incapable of processing all of the relevant pieces of information, but under the influence of biases as mental shortcuts to the solution of the problem, they do process them by simplifying the decision-making process. In the stated context, decision-makers make a choice based on the application of the simplified rules and inadequate models of decision-making, which negatively affects the outcome of the decision-making process (Figure 1).

\section{BIASES AS THE BEHAVIORAL ASPECTS OF THE DECISION-MAKING PROCESS}

For the purpose of discovering the causes and consequences of the biases arising under the influence of certain mental mistakes, certain authors have been researching this field for more than two decades now. Making general conclusions is not a simple process, since it is necessary that not only the economic, but also the psychological dimension of certain phenomena and occurrences, as well as the personal characteristics of decision-makers that can influence their behavior, should be perceived. Starting from numerous empirical studies in this field (Tversky \& Kahneman, 1974; Kahneman \& Tversky, 1979; Chi \& Fan, 1997; Busenitz \& Barney, 1997; Hodgkinson, Maule, Bown, Pearman \& Glaister, 2002; Roxburg, 2003; Korte, 2003; Forbes, 2005; Hammond, Keeney \& Raiffa, 2006; Jamieson \& Hyland, 2006; Chira, Adams \& Thornton, 2008; Henman, 2008; Maqsood Finegan \& Walker, 2008; McKenzie, van Winkelen \& Grewal, 2011; Sklad \& Diekstra, 2013; Bresnick \& Parnell, 2013; Riaz \& Iqbal, 2015; Fiedler \& von Sydow, 2015; Howard \& Abbas, 2016; Mustilli, Piccolo \& D'Angelo, 2018), the framing effect, the availability bias, representativeness, the anchoring effect and adjustment, the status quo, the sunk costs effect, a confirmation, a false consensus, overconfidence and

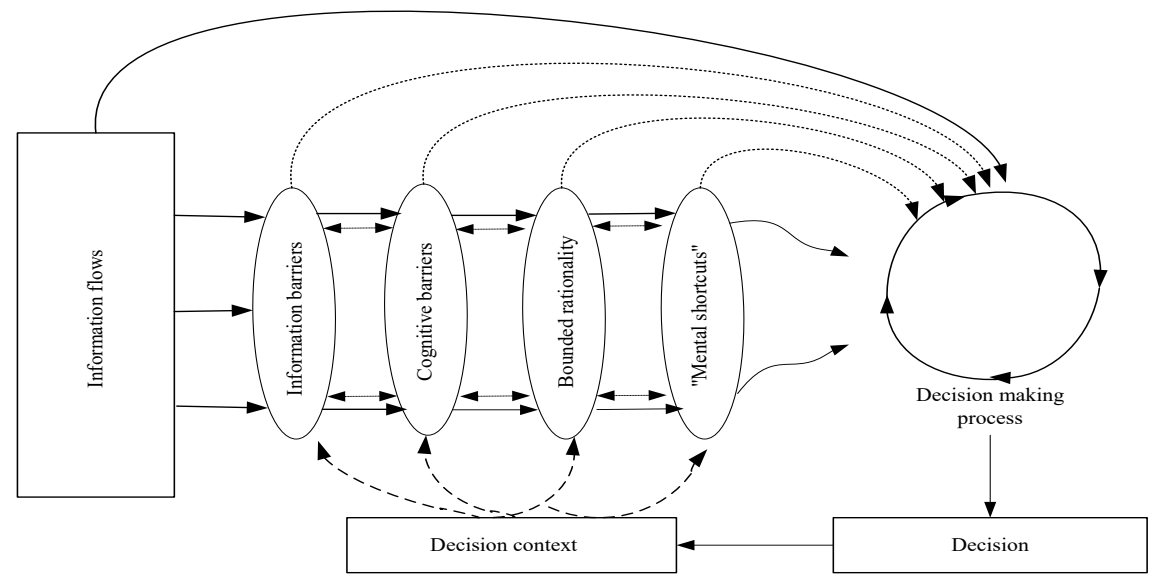

Figure 1 Bounded rationality in decision-making

Source: Author, based on Jamieson \& Hyland, 2006 
the illusion of control have been identified in this paper as the most common biases that shape the outcome of the decision-making process.

\section{The Framing Effect}

The first step in the decision-making process is the formulation of the problem that is to be solved. The manner in which decision-makers identify the problem can depend on the influence of the manner in which "the problem is being framed" (Henman, 2008; Pavličić, 2015, 314; Howard \& Abbas, 2016, 357). The most common obstacle to an objective insight and a correct problem diagnosis, as the basic steps in the phase of the problem identification, is the shaping of the decision-maker's perception depending on the manner in which the information has been presented (Bresnick \& Parnell, 2013, 36). This effect is also known as the axiom of invariance, according to which the redefining of the problems will not affect the result of the choice, which means that the preferences of decision-makers are independent of the manner in which problems are described (Tversky \& Kahneman, 1974). However, the axiom of invariance is often disputed, since the preferences are variable, and when comparing alternatives, it often leads to the variation of the attributes that are being subjected to consideration, which all taken together affects the occurrence of the intransitivity of preferences. In practice, a fact has been established that decisionmakers prefer the positive to the negative frame of the problem formulation, and that, together with a change in the manner of the interpretation of information, they also change their attitudes (Tversky \& Kahneman, 1974; Kahneman \& Tversky, 1979; Jamieson \& Hyland, 2006; Hammond et al, 2006; Chira, Adams \& Thornton, 2008; McKenzie et al, 2011; Bresnick \& Parnell, 2013, 36). As the the frame in which possible outcomes have been shown changes, the reference point changes as well, which leads to the shaping of the preferences of decision-makers and their relation to the risk (Božović \& Gvozdenović, 2009). The observed aversion towards losses is related to a greater tendency of decision-makers to avoid a loss rather than realize a gain (Tverski \& Kahneman, 1979). The tendency towards risky decisions will also be more expressed when the problem is "negatively framed". A. Tverski and D. Kahneman (1974) are first to have confirmed that losses are emotionally experienced twice as strongly in comparison to comparable gains, which can distort the perception of decision-makers in the phase of the problem identification.

\section{The Availability Bias}

Under the influence of the availability bias, decisionmakers estimate the probability of one event depending on their own memory, namely depending on the extent to which they can remember similar events (Hammond et al, 2006; Sklad \& Diekstra, 2013). If the same or a similar event often occurred in the past, decision-makers can more easily imagine its occurrence, while they remember rare events with more difficulties. Consequently, a high probability of occurrence is attributed to the event that frequently occurred in the past, whereas a low probability of occurrence is attributed to the event that rarely occurred in the past (Pavličić, 2015, 301). The consequence of such a perception is a distorted opinion of the decision-maker's and the unbiased estimation of the probability of events, due to which he can make wrong choices (Korte, 2003). The estimation of future events, as well as risks, is more dependent on the memory of decision-makers than on the unbiased evaluation of possible events (Fiedler \& Sydow, 2015). Decision-makers predict the frequency of some event depending on the information available in their memory, the one which shapes their judgment and leads to a selective perception (Hammond et al, 2006; Henman, 2008; Maqsood et al, 2008; Bresnick \& Parnell, 2013, 37). The foregoing means that decisionmakers wrongly estimate and predict the probabilities of future events which the outcome of decisionmaking depends, under the influence of the selective memory of past events (Howard \& Abbas, 2016, 351).

\section{Representativeness}

Representativeness is the application of mental shortcuts in determining conditional probabilities on the basis of the estimation of the extent to which some 
event is a result of a certain process, i.e. of the extent to which a certain process generates the analyzed event (Maqsood et al, 2008; Sklad \& Diekstra, 2013; Fiedler \& von Sydow, 2015). In fact, it is about the estimation of the probabilities of conditional events often based on the incorrect similarity and connection of certain events and occurrences (Howard \& Abbas, 2016, 352). Representativeness was for the first time described by A. Tverski and D. Kahneman (1974), who described it as one of the most common biases. These authors indicated the occurrence in which, in certain situations, decision-makers show a tendency to generalize the conclusions on the observed phenomenon on the basis of the analysis of but a few attributes or selective observations regarding a certain occurrence. Certain studies dealing with the examination of the influence of representativeness have shown that decision-makers tend to ignore the basic information about a certain occurrence (Chi \& Fan, 1997). Decision-makers underestimate the possibility of an error with such estimations, as well as the unreliability inherent to small data samples. In fact, a special form of representativeness is related to the readiness of decision-makers to generalize the attitudes on the basis of the examinations based on small samples or personal experience (Busenitz \& Barney, 1997).

\section{The Anchoring Effect and the Adjustment Bias}

The bias known in theory as the "anchoring effect" is that related to the shaping of the decisionmaker's perception depending on the available information and the initial attitude (Maqsood et al, 2008; Howard \& Abbas, 2016, 355). Decision-makers' initial estimations have a greater specific weight in relation to the pieces of information collected in a later course, due to which decision-makers become biased in judgment (Hammond et al, 2006; Henman, 2008; McKenzie et al, 2011; Sklad \& Diekstra, 2013; Pavličić, 2015, 302). It means that the chosen value representing the so-called anchor is the starting point, only to subsequently be corrected, depending on other relevant factors. The adjustment process is most often such that the judgment of decision-makers depends on the initial anchor (Fiedler \& von Sydow, 2015). The anchors can have different forms. One of the most common types of anchor is a past event or trend (Hammond et al, 2006, 119). Old data have the anchors corrected by decision-makers, whereby the need for an objective adjustment to a new situation is disregarded (Bresnick \& Parnell, 2013, 37). In the conditions characterized by fast changes on the market, the application of the anchor leads to bad predictions and wrong choices (Roxburg, 2003).

\section{The Status Quo}

Decision-makers demonstrate a strong bias towards the alternatives that support the status quo, especially in the situations when changes need to be implemented (McKenzie et al, 2011). Decision-makers prefer the status quo state as a less risky alternative, due to which taking actions whose implementation would disturb such a state is often avoided (Samuelson \& Zeckhauser, 1988; Hammond et al, 2006; Henman, 2008). The change of the status quo state means taking actions, and therefore assuming responsibility and the consequences that occur as a result of the taken action (Maitland \& Sammartino, 2015). Maintaining the status quo state is in the majority of cases an easier way to solve problems since it implies a lesser risk, due to which fact decision-makers most often look for reasons which they can call upon to justify such a behavior of theirs (Bresnick \& Parnell, 2013, 37). Still, it does not mean that the choice of the status quo state is always wrong. It is really challenging for decisionmakers to make a difference between the status quo option, which at a certain moment is a rational choice, and the status quo option which is the resulting aversion towards risk and changes (Roxburg, 2003).

\section{The "Sunk Cost" Effect}

The effect of sunk, i.e. unjustified costs is a consequence of the observed phenomenon that decision-makers often try to justify the outcomes of their bad decisions in the past by presenting new choices (Roxburg, 2003; McKenzie et al, 2011; Pavličić, $2015,315)$. It means it comes to the favoring of the choice of the alternative that supports the decisions 
promulgated earlier, even when they are not justified. In that way, past decisions become what is defined as sunk costs, i.e. "old investments that cannot be restored". The costs that occur as a consequence of the decisions made in the past are irrelevant for future decisions, and yet they determine the decisionmaking process and its outcome. The sunk cost effect is related to the phenomenon of an aversion towards risk, which leads to the decisions whose application means the minimization of the already lost resources, not the maximization of the expected usefulness. This manner of decision-making is most frequently present in a situation when a decisionmaker has to take responsibility for the bad outcome. In other words, there is a significant correlation between the taken responsibility and the amount of the invested assets in a certain design (Chira at al, 2008). The sunk cost effect appears because decisionmakers consciously or unconsciously do not want to admit their own mistake and take responsibility (Hammond et al, 2006; Henman, 2008). It most often arises together with the status quo effect, if the status quo alternative is precisely the one which a decisionmaker has excessively invested in and which he/she wants to justify.

\section{The Confirmation Basis}

The need for confirmation implies a search for information supportive of the decision-maker's attitude, whereas the information that indicates possible mistakes and a bad outcome is ignored (McKenzie et al, 2011). This bias arises as a consequence of the tendency of decision-makers to find arguments that confirm the established problem diagnosis, while those arguments against the acceptance of such an attitude are rejected, even if they are convincible and rational (Pavličić, $2015,372)$. It means that the need for confirmation leads to a biased choice to be made by decisionmakers, i.e. the one based on the unreal confirmation of the original attitude or the decisions already made (Bresnick \& Parnell, 2013, 37). This effect often occurs as a consequence of the excessive self-confidence of decision-makers with respect to the correctness of a decision and their infallibility when the estimation of alternatives is concerned. A selective and biased analysis of the content of information which the initial attitude is supported by commonly occurs in the decision-making process (Jamieson \& Hyland, 2006; Hammond et al, 2006). Decision-makers only accept the information that justifies the decisions they have made in a prior period and reject and/or have a critical and negative attitude towards the pieces of information that could question their prior choices (Chira et al, 2008).

\section{A False Consensus}

Decision-makers subjectively and biasedly estimate the degree to which their associates follow and support their attitudes and beliefs (Hammond et al, 2006). Such a behavior is only positive if decisionmakers make a rational choice. The research studies have shown that there are many factors whose influence causes the abovementioned effect (Roxburg, 2003, 26): the tendency of decision-makers to only accept the opinions and arguments that support their attitudes, ideas and suggestions; selective memory, i.e. the habit of only remembering the facts and experiences that strengthen the original assumptions; a biased evaluation, i.e. the fast acceptance of proofs in favor of the set hypotheses, whereas contradictory proofs are exposed to rigorous evaluation and almost certain rejection; a group opinion, i.e. pressure to reach a high level of consent within a single group. High cohesion encourages the occurrence of a group opinion and can negatively affect the rationality in the judgment of the group members as decision-makers, since it reduces their ability to objectively perceive the problem under the influence of the opinion expressed by the other members (Henman, 2008; Pavličić, 2015, 439).

\section{Overconfidence}

Overconfidence is related to the high self-confidence that affects decision-makers when they estimate personal abilities and knowledge boundaries. Under the influence of too high a level of the self-confidence based on the attitude that their abilities are exceptional, decision-makers as limitedly rational individuals 
have a tendency to overestimate their ability to make good decisions, and make hasty and imprudent decisions instead (Chira et al, 2008; Riaz \& Iqbal, 2015). In fact, when decision-makers have an unrealistically high opinion of their own abilities and think they know more than it is objective, they most often make bad decisions that arise as a result of the biasedly estimated probabilities and outcomes of future events (Roxburg, 2003; Hammond et al, 2006). Overconfidence relates to the overestimation of favorable against unfavorable outcomes without observing and without an analysis of all of the relevant pieces of information (Busenitz \& Barney, 1997; Jamieson \& Hyland, 2006; Chira et al, 2008). The estimation of the probability of events and the predicting of future outcomes are not completely reliable; they are often the result of the overconfidence that arises when decisionmakers either do not notice the dangers or ignore them (Golden, Milievicz \& Herbig, 1994). This effect has negative consequences to the development and implementation of long-term strategies, since most of them are based on unreal, optimistic estimations of future events (Roxburg, 2003; Henman, 2008). However, although overconfidence can be observed as a widely spread cognitive bias, certain research studies have confirmed the fact that the level of selfconfidence and optimism varies between individuals and can be related to the personal characteristics of decision-makers, such as their sex, age and education (Simon \& Houghton, 2003; Forbes, 2005).

\section{The Illusion of Control}

The illusion of control occurs when decision-makers overestimate the level at which the outcomes of a decision are under their own control. It is related to the overestimation of decision-makers' personal ability to successfully solve complex problems and make effective decisions. The abovementioned effect is most often manifested with decision-makers who have made good decisions in a prior period. Decision-makers are often under the influence of the illusion of control, while simultaneously ignoring the uncontrolled factors that can affect their final choice (Jamieson \& Hyland, 2006; Henman, 2008). The illusion of control can be understood as a tendency of individuals to unrealistically believe that they can control and/or affect the outcomes in the situations that are beyond their own control. The mentioned bias makes decision-makers believe they can affect the outcome, even when it is impossible (Chira et al, 2008; Pavličić, 2015, 401). This bias is related to decisionmakers' ungrounded self-confidence and optimism, since the influence of overconfidence encourages the occurrence of the illusion of control, i.e. an excessive belief in personal success, even when it is contrary to the objective facts (Riaz \& Iqbal, 2015).

\section{RECOMMENDATIONS FOR OVERCOMING BIASES IN THE DECISION-MAKING PROCESS}

Pursuant to the review research of the influence of biases on the decision-making process, it is possible to conclude that mistakes in individual decision-making arise due to routine problem solving, the irregular application of heuristics and different deformations in thinking caused by certain psychological factors (Table 1). Starting from the negative effects of the analyzed biases, one of the basic research challenges in the field of strategic decision-making is that related to the exploration of the possibilities of overcoming them. The basic assumption of the mitigation of the systematic mistakes that lead to bad outcomes is that decision-makers prevent the negative effect of biases.

It is primarily necessary for everyone to be aware of the influence of biases on the ability to judge and predict a future event, and also to apply a critical approach in the decision-making process. On the basis of the analysis of the causes of the identified biases, the possibilities of overcoming them have been identified (Table 1). The collection and analysis of all of the relevant pieces of information which the outcome of the decision-making process depends on, as well as the raising awareness of decision-makers regarding their opining that their own decisions can be wrong is the starting point in the process of overcoming the identified biases (Hodgkinson et al, 2002; Roxburg, 2003; Hammond et al, 2006). 
For the purpose of overcoming the negative influence of the framing effect, decision-makers should observe a problem from different perspectives in order to notice all of the relevant aspects of the set problem. When the manner of the formulation, i.e. presentation of a problem is concerned, one should think of it in all the phases of the decision-making process, not only in the problem identification phase. For the purpose of finding new alternatives for problem solving, in the final phase of the decision-making process it is purposeful to return to the initial problem identification phase and change the perspective of observation. The stated recommendation is in accordance with the understanding that the "problem frame" determines the decision context in which a problem is subjected to observation and shapes the choice of the elements that are important in the analysis of the problem. Since the decision-making process is a cyclic process, not a set of linear activities, a change in the problem frame can affect the course of decision-making.

The negative influence of the availability bias and representativeness can be reduced if decision-makers determine the probability of events on the basis of an objective analysis of the relevant data, regardless of the frequency of their arising in the past. The basic assumption is one's possession of the necessary knowledge and skills, as well as a rational analysis of the related events and processes independently of the decision-maker's prior experience. In fact, it is necessary to give less importance to the pieces of information already collected in relation to the need for collecting new information that can lead to changes in predicting the probability and the outcome of future events.

One of the ways to eliminate the anchoring effect is to apply the alternative approaches in the process of problem solving that do not rely on decision-makers' past experiences. Decision-makers should be open to new ideas and suggestions. It is desirable to hear different opinions in order to expand the original ideas and the approach in exploring the problem that should lead to the best solution. Also, decision-makers should be objective when considering their associates' suggestions, and should not impose their own ideas as possible solutions.
The choice of the status quo option can, in certain situations, be the best solution, but it does not mean that it should always be followed. The status quo should not be observed as the only alternative, but it is necessary for decision-makers to identify and analyze a greater number of different options, carefully evaluating the advantages and disadvantages of each of them. In situations when decision-makers support the status quo, they should ask themselves the question whether they would choose such an alternative if it meant a certain level of risk. Except for the abovementioned recommendation, decisionmakers should also reconsider the set aims in order to objectively observe whether they are satisfied with the existing state or it is necessary that certain changes should be made regardless of the effort and the costs demanded by such changes.

The decisions that have a certain "history" are very hard to objectively observe since certain psychological factors that determine their ability to judge and the manner of decision-making affect decision-makers. In that sense, overcoming the effect of sunk costs is based on respecting the opinion and suggestions of those actors of the decision-making process who were not included in making previous decisions. A decision-maker should reconsider the reasons why he/she does not want to admit the mistake and bear relevant consequences. Most often, the key reason is the damaged reputation and self-respect of decisionmaker. In that sense, the culture that causes the fear of failure and leads to the fact that decision-makers do not want to admit their mistakes should be discouraged.

The influence of confirmation is possible to overcome if decision-makers are ready to critically reconsider the decisions made earlier. One should primarily check whether all of the alternatives are assessed on the basis of the same criteria and then examine the arguments that support the suggested alternative. Decision-makers should objectively analyze the personal motives that support the decision made. The recommendation is that a decision-maker should observe whether he/she collects information for the purpose of improving the quality of choice or his/ her basic motive is to confirm the chosen course of 
Table 1 The review research of the influence of the biases on the decision-making process

\begin{tabular}{|c|c|c|}
\hline RESEARCH OF BIASES & MEANING OF BIASES & $\begin{array}{l}\text { RECOMMENDATION FOR OVERCOMING } \\
\text { BIASES }\end{array}$ \\
\hline \multicolumn{3}{|l|}{ Framing effect } \\
\hline $\begin{array}{l}\text { Tversky \& Kahneman, 1974; } \\
\text { Kahneman \& Tversky, 1979; } \\
\text { Hammond et al, 2006; } \\
\text { Henman, 2008; } \\
\text { Chira et al, 2008; } \\
\text { McKenzie et al, 2011; } \\
\text { Bresnick \& Parnell, 2013; } \\
\text { Howard \& Abbas, } 2016\end{array}$ & $\begin{array}{l}\text { The preferences of decision-makers are } \\
\text { independent of the ways of describing } \\
\text { problems. } \\
\text { Different approaches in defining the } \\
\text { problem lead to change in decision- } \\
\text { makers' preferences. }\end{array}$ & $\begin{array}{l}\text { In the problem identification phase, } \\
\text { decision-makers should observe the } \\
\text { problem from different perspectives. } \\
\text { In the final phase of the decision-making } \\
\text { process, it is purposeful to return to the } \\
\text { initial problem identification phase and } \\
\text { change the perspective of observation in } \\
\text { order to generate new options. }\end{array}$ \\
\hline \multicolumn{3}{|l|}{ Availability bias } \\
\hline $\begin{array}{l}\text { Tversky \& Kahneman, 1974; } \\
\text { Korte, 2003; } \\
\text { Hammond et al, 2006; } \\
\text { Henman, 2008; } \\
\text { Maqsood et al, 2008; } \\
\text { Bresnick \& Parnell, 2013; } \\
\text { Sklad \& Diekstra, 2014; } \\
\text { Fiedler \& von Sydow, 2015; } \\
\text { Howard \& Abbas, } 2016\end{array}$ & $\begin{array}{l}\text { The estimation of future events, as well } \\
\text { as their outcomes, is more dependent } \\
\text { on the decision-maker's memory than } \\
\text { on the unbiased evaluation of possible } \\
\text { events. }\end{array}$ & $\begin{array}{l}\text { Determine the probability of events on } \\
\text { the basis of an objective analysis of the } \\
\text { relevant data, regardless of the frequency } \\
\text { of their arising in the past and the } \\
\text { decision-maker's experience. } \\
\text { It is necessary to give less importance to } \\
\text { the already collected information. }\end{array}$ \\
\hline \multicolumn{3}{|l|}{ Representativeness } \\
\hline $\begin{array}{l}\text { Tversky \& Kahneman, 1974; } \\
\text { Chi \& Fan, 1997; } \\
\text { Busenitz \& Barney, 1997; } \\
\text { Maqsood et al, 2008; } \\
\text { Sklad \& Diekstra, 2014; } \\
\text { Fiedler \& von Sydow, 2015; } \\
\text { Howard \& Abbas, } 2016\end{array}$ & $\begin{array}{l}\text { Determine conditional probabilities } \\
\text { on the basis of the estimation of the } \\
\text { extent to which some event is a result } \\
\text { of a certain process, i.e. the extent to } \\
\text { which a certain process generates the } \\
\text { analyzed event. }\end{array}$ & $\begin{array}{l}\text { Determine conditional probabilities on the } \\
\text { basis of an objective assessment, not on } \\
\text { the basis of a subjective conclusion. } \\
\text { Examine the causal connection between } \\
\text { conditional events. }\end{array}$ \\
\hline \multicolumn{3}{|l|}{ Anchoring effect } \\
\hline $\begin{array}{l}\text { Roxburg, 2003; } \\
\text { Hammond et al, 2006; } \\
\text { Henman, 2008; } \\
\text { McKenzie et al, 2011; } \\
\text { Bresnick \& Parnell, 2013; } \\
\text { Sklad \& Diekstra, 2014; } \\
\text { Fiedler \& Sydow, 2015 }\end{array}$ & $\begin{array}{l}\text { The shaping of the decision-maker's } \\
\text { perception depending on the available } \\
\text { information and the initial attitude, } \\
\text { which have a greater specific weight } \\
\text { in relation to the information collected } \\
\text { later. }\end{array}$ & $\begin{array}{l}\text { Apply alternative approaches in the } \\
\text { problem solving process. } \\
\text { Decision-makers should be open to new } \\
\text { ideas and suggestions that may affect } \\
\text { change in the initial state. }\end{array}$ \\
\hline \multicolumn{3}{|l|}{ Status quo } \\
\hline $\begin{array}{l}\text { Samuelson \& Zeckhauser, 1988; } \\
\text { Roxburg, 2003; } \\
\text { Hammond et al, 2006; } \\
\text { Henman, 2008; } \\
\text { McKenzie et al, 2011; } \\
\text { Bresnick \& Parnell, 2013; } \\
\text { Maitland \& Sammartino, } 2015\end{array}$ & $\begin{array}{l}\text { Decision-makers show a strong bias } \\
\text { towards the alternatives that support } \\
\text { the status quo state as a less risky } \\
\text { alternative. } \\
\text { It can be associated with risk aversion } \\
\text { and the implementation of changes. }\end{array}$ & $\begin{array}{l}\text { The status quo option should not be seen } \\
\text { as the only alternative, but it is rather } \\
\text { desirable to develop a number of options } \\
\text { and carefully evaluate their benefits. } \\
\text { Examine whether the status quo is really } \\
\text { the best option when it means a certain } \\
\text { level of risk. }\end{array}$ \\
\hline
\end{tabular}




\begin{tabular}{|c|c|c|}
\hline \multicolumn{3}{|l|}{ Sunk costs effect } \\
\hline $\begin{array}{l}\text { Roxburg, 2003; } \\
\text { Hammond et al, 2006; } \\
\text { Chira at al, 2008; } \\
\text { Henman, 2008; } \\
\text { McKenzie et al, } 2011\end{array}$ & $\begin{array}{l}\text { Decision-makers are trying to justify the } \\
\text { outcome of earlier bad decisions made } \\
\text { by the new choices - the favoring of the } \\
\text { choice of the alternative that supports } \\
\text { the decisions made earlier in the past. }\end{array}$ & $\begin{array}{l}\text { The culture that causes the fear of failure } \\
\text { and leads to the fact that decision-makers } \\
\text { do not want to admit their mistakes } \\
\text { should be discouraged. } \\
\text { Engage individuals who have not been } \\
\text { involved in making previous decisions. }\end{array}$ \\
\hline \multicolumn{3}{|l|}{ Confirmation } \\
\hline $\begin{array}{l}\text { Hammond et al, 2006; } \\
\text { Jamieson \& Hyland, 2006; } \\
\text { Henman, 2008; } \\
\text { McKenzie et al, 2011; } \\
\text { Bresnick \& Parnell, } 2013\end{array}$ & $\begin{array}{l}\text { Biased information gathering and } \\
\text { decision-makers' choice based on the } \\
\text { unrealistic confirmation of the original } \\
\text { attitude or the decisions already made. }\end{array}$ & $\begin{array}{l}\text { Check whether all of the alternatives are } \\
\text { assessed on the basis of the same criteria. } \\
\text { Examine the arguments supportive of the } \\
\text { suggested alternative and also encourage } \\
\text { a critical view of the choice of the best } \\
\text { alternative. }\end{array}$ \\
\hline \multicolumn{3}{|l|}{ False consensus } \\
\hline $\begin{array}{l}\text { Roxburg, 2003; } \\
\text { Hammond et al, 2006; } \\
\text { Henman, } 2008\end{array}$ & $\begin{array}{l}\text { Decision-makers subjectively and } \\
\text { biasedly estimate the degree to which } \\
\text { their associates follow and support their } \\
\text { attitudes and beliefs. }\end{array}$ & $\begin{array}{l}\text { Creating a culture that encourages a } \\
\text { creative conflict. } \\
\text { The actors of the decision-making process } \\
\text { should encourage constructive criticism. }\end{array}$ \\
\hline \multicolumn{3}{|l|}{ Overconfidence } \\
\hline $\begin{array}{l}\text { Golden et al, 1994; } \\
\text { Busenitz \& Barney, 1997; } \\
\text { Roxburg, 2003; } \\
\text { Simon \& Houghton, 2003; } \\
\text { Forbes, 2005; } \\
\text { Hammond et al, 2006; } \\
\text { Jamieson \& Hyland, 2006; } \\
\text { Henman, 2008; } \\
\text { Chira et al, 2008; } \\
\text { Riaz \& Iqbal, 2015 }\end{array}$ & $\begin{array}{l}\text { Overconfidence relates to the } \\
\text { overestimation of favorable against } \\
\text { unfavorable outcomes. It occurs when } \\
\text { decision-makers unrealistically and } \\
\text { optimistically overestimate future } \\
\text { events without analyzing all of the } \\
\text { relevant pieces of information. }\end{array}$ & $\begin{array}{l}\text { The application of a rational approach } \\
\text { to the prediction and evaluation of the } \\
\text { probabilities of events. } \\
\text { It is necessary to reconsider the } \\
\text { justification of one's personal } \\
\text { assumptions and estimation of outcomes. } \\
\text { Reconsider the established cause and } \\
\text { effect relations resulting from decision- } \\
\text { makers' too high self-confidence. }\end{array}$ \\
\hline \multicolumn{3}{|l|}{ Illusion of control } \\
\hline $\begin{array}{l}\text { Jamieson \& Hyland, 2006; } \\
\text { Henman, 2008; } \\
\text { Chira et al, 2008; } \\
\text { Riaz \& Iqbal, } 2015\end{array}$ & $\begin{array}{l}\text { Decision-makers overestimate the level } \\
\text { at which the outcomes of a decision are } \\
\text { under their control. }\end{array}$ & $\begin{array}{l}\text { The encouragement of the critical } \\
\text { reconsideration of personal abilities and } \\
\text { the power on the part of decision-makers. }\end{array}$ \\
\hline
\end{tabular}

Source: Author

action. The incentive for a decision-maker's critical attitude is the necessary assumption of overcoming the mentioned influence.

The best way to mitigate the false consensus influence is to create a culture that encourages a creative conflict. The actors of the decision-making process should encourage constructive criticism, as well as new creative suggestions. A critical approach should be observed as useful and desirable, not as "an act of the enemy". The recommendation is that, for each argument in favor of the chosen option, a counterargument should be presented; this is also desirable for the purpose of carrying out a comprehensive and objective analysis.

One of the recommendations for the purpose of overcoming overconfidence is the application of a rational approach in the prediction and evaluation of probabilities. All decision-maker's assumptions should carefully be examined and compared with relevant data in order to reduce the influence of 
personal impressions. The recommendation for decision-makers is not to be biased in the process filtration and the analysis of the collected information. It is necessary to reconsider the established cause and effect relations that are often the product of decision-makers' too high self-confidence as well as the justification of their personal assumptions and attitudes. Starting from their interconnectedness of overconfidence and the illusion of control, a similar approach to overcoming the negative consequences of the illusion of control is recommended. The encouragement of the critical reconsideration of one's personal abilities and the power that decision-makers have is considered as the basic assumption of the mitigation of the abovementioned negative effects of the illusion of control that can cause the promulgation of bad decisions.

\section{CONCLUSION}

In spite of the effort indicating that the rational models of choice should be applied, decision-makers often make bad decisions. The basic reasons for making bad decisions are a lack of the commitment and the bounded rationality of decision-makers. The effects of bounded rationality determine the manner in which decision-makers make a choice. Depending on the context which decisions are made in, different behavioral factors shape the manner in which decision-makers collect, filtrate, process and analyze information in the decision-making process and make choices. The abovementioned means that, due to the limitation of their cognitive capacities, decision-makers lean on the simplified solving of complex problems through the application of mental shortcuts. Cognitive limitations lead to predictable and consistent mental mistakes caused by such a simplified collection, analysis and processing of information. Some of the defined cognitive limitations refer to the formulation of a problem, others are related to the evaluation of the probabilities of relevant events, whereas there are those that arise as a consequence of the wrong perception of decisionmakers' personal abilities. Decision-makers consider a problem through the prism of their own subjective opinions and beliefs, relying on prior events and the existing information.

This kind of opinion refers to the conclusion that mistakes in decision-making arise due to having problems solved in a routine manner, the application of heuristics as mental shortcuts and the different deformations in thinking caused by certain psychological factors, by which the starting hypothesis is confirmed. In accordance with the foregoing, the contribution of the paper in the theoretical sense reflects in the identification of different biases and the understanding of their influence on the outcome of the decision-making process. In the practical sense, the defined recommendations for the mitigation of the negative influence of the biases on decisionmakers' perceptions and attitudes can help decisionmakers improve the decision-making process in real situations. Also, the derived conclusions stand for a good basis for the implementation of the research study, by which the causes and consequences of the analyzed biases would empirically be tested. Still, the basic limitation of the research study is reflected in drawing conclusions on the basis of the literature review and the secondary data, without the implementation of the original empirical research. In accordance with the above-stated, the directions of a future research study rely on the development of a research model based on the drawn conclusions of the implemented quality analysis of the influence of the identified biases for the purpose of the empirical verification of the set hypothesis.

\section{REFERENCES}

Babić, V. (1995). Strategijsko odlučivanje. Beograd, Republika Srbija: Institut za ekonomiku i finansije.

Božović, B., \& Gvozdenović, V. (2009). Nerealistični optimizam i donošenje odluka. Psihologija, 42(4), 567-584.

Bresnick, A. T., \& Parnell, S. G. (2013). Decision-making challenges. In S. G. Parnell, A. T. Bresnick, N. S. Tani, \& E.R. Jonson (Eds.). Handbook of Decision Analysis (pp. 22-46). New Jersey: John Wiley \& Sons 
Busenitz, L., \& Barney, J. (1997). Differences between entrepreneurs and managers in large organizations: Biases and heuristics in strategic decision-making. Journal of Business Venturing, 12(1), 9-30. doi.org/10.1016/S08839026(96)00003-1

Campitelli, G., \& Gobet, F. (2010). Herbert Simon's decisionmaking approach: Investigation of cognitive processes in experts. Review of General Psychology, 14(4), 354-364. doi. org/10.1037/a0021256

Chi, T., \& Fan, D. (1997). Cognitive limitations and investment 'myopia'. Decision Sciences, 28(1), 27-57. doi. org/10.1111/j.1540-5915.1997.tb01301.x

Chira, I., Adams, M., \& Thornton, B. (2008). Behavioral bias within the decision making process. Journal of Business $\mathcal{E}$ Economics Research, 6(8), 11-20. doi:10.19030/jber.v6i8.2456

De Neys, W. (2010). Heuristic bias, conflict, and rationality in decision-making. In B. M. Glatzeder, V. Goel., \& A. Müller (Eds.). Towards a Theory of Thinking, On Thinking (pp. 22-33). Berlin: Springer, doi:10.1007/978-3-642-03129-8_2

Fiedler, K., \& von Sydow, M. (2015). Heuristics and biases: Beyond Tversky and Kahneman's (1974) judgment under uncertainty. In M. Eysenck \& D. Groome (Eds.). Revisiting the Classical Studies (pp. 146-161). Sage Publications, Retrieved March 9, 2018, from https://www.researchgate. net/publication/280981235_Heuristics_and_Biases_ Beyond_Tversky_and_Kahneman\%27s_1974_Judgment_ under_Uncertainty

Forbes, D. (2005). Are some entrepreneurs more overconfident than others? Journal of Business Venturing, 20(5), 623-640. doi. org/10.1016/j.jbusvent.2004.05.001

Golden, J., Miliwicz, J., \& Herbig, P. (1994). Forecasting: Trials and Tribulations. Management Decision, 32(1), 33-39.

Hammond, J., Keeney, R., \& Raiffa, H. (2006). The hidden traps in decision making. Harvard Business Review, 84(1), 118-127.

Harrison, F. (1996). A Process Perspective on Decision Making. Management Decision, 34(1), 46-53. doi. org/10.1108/00251749610106972

Henman, D. L. (2008). How to avoid the hidden traps of decision making. Retrieved March 9, 2018, from http://www. henmanperformancegroup.com/articles/Avoid-HiddenTraps.pdf
Hodgkinson, G., Maule, J., Bown, J., Pearman, A., \& Glaister, K. (2002). Further reflections on the elimination of framing bias in strategic decision making. Strategic Management Journal, 23(11), 1069-1076. doi:10.1002/smj.266

Howard, A.R., \& Abbas, E. A. (2016). Foundation of Decision Analysis. England: Pearson Education Limited

Huber, G. (1980). Managerial Decision Making. London, UK: Longman Higher Education

Jamieson, K., \& Hyland, P. (2006). Good intuition or fear and uncertainty: The effects of bias on information systems selection decisions. Informing Science: International Journal of an Emerging Transdiscipline, 9, 49-69. Retrieved March 5, 2018, from http://inform.nu/Articles/Vol9/v9p049-069Jamieson60. pdf

Kahneman, D., \& Tversky, A. (1979). Prospect theory: An analysis of decision under risk. Econometrica, 47(2), 263-291. doi:10.2307/1914185

Korte, F. R. (2003). Biases in Decision Making and Implications for Human Resource Development. Advances in Developing Human Resources, 5(4), 440-457. doi. org $/ 10.1177 / 1523422303257287$

Levinthal, D. (2011). A behavioral approach to strategy What's the alternative? Strategic Management Journal, 32(13), 1517-1523. doi:10.1002/smj.963

Maitland, E., \& Sammartino, A. (2015). Decision making and uncertainty: the role of heuristics and experience in assessing a politically hazardous environment. Strategic Management Journal, 36(10), 1554-1578. doi:10.1002/smj.2297

Maqsood, T., Finegan, A., \& Walker, D. (2008). Biases and heuristics in judgment and decision making: The dark side of tacit knowledge. Informing Science and Information Technology, 1, 295-301. doi: 10.28945/740

March, J. (1994). A Primer on Decision Making: How Decision Happen. New York, NY: A Free Press.

McKenzie, J., van Winkelen, C., \& Grewal, S. (2011). Developing organisational decision making capability: a knowledge manager's guide. Journal of Knowledge Management, 15(3), 403-421. doi:10.1108/13673271111137402

Menon, A. (2018). Bringing cognition into strategic interactions: Strategic mental models and open questions. Strategic Management Journal, 39(1), 168-192. doi:10.1002/ smj. 2700 
Mustilli, M., Piccolo, R., \& D’Angelo, E. (2018). Crosscountry differences in how behavioral biases affect decision - making in the bank industry: Evidence from Italy and Serbia. American Journal of Industrial and Business Management, 8, 239-249. Retrieved January 18, 2018, from https://doi.org/10.4236/ajibm.2018.82016

Pavličić, D. (2015). Teorija odlučivanja. Beograd, Republika Srbija: Ekonomski fakultet Univerziteta u Beogradu.

Riaz, T., \& Iqbal, H. (2015). Impact of overconfidence, illusion of control, self control and optimism bias on investors decision making: Evidence from developing markets. Research Journal of Finance and Accounting, 6(11), 110-116.

Roxburg, C. (2003). Hidden flaws in strategy. The McKinsey Quarterly, 27(2), 21-30. Retrieved January 28, 2018, from https://www.mckinsey.com/business-functions/strategyand-corporate-finance/our-insights/hidden-flaws-instrategy

Samuelson, W., \& Zeckhauser, R. (1988). Status quo bias in decision making. Journal of Risk and Ucertainty, 1(1), 7-59. Retrieved Retrieved March 6, 2018, from https://link. springer.com/journal/11166

Simon, H. (1955). A Behavioral Model of Rational Choice. The Quarterly Journal of Economics, 69(1), 99-118. doi:10.2307/1884852

Simon, H. (1959). Theories of Decision Making in Economics and Behavioral Science. American Economic Review, 49(3), 253-283.
Simon, M., \& Houghton, S. (2003). The relationship between overconfidence and the introduction of risky products: Evidence from a field study. The Academy of Management Journal, 46(2), 139-149. doi:10.2307/30040610

Sklad, M., \& Diekstra, R. (2014). The development of the heuristics and biases scale. Procedia - Social and Behavioral Sciences, 112, 710-718. doi:10.1016/j.sbspro.2014.01.1221

Tiwana, A., Wang, J., Keil, M., \& Ahluwalia, P. (2007). The bounded rationality bias in managerial valuation of real options: Theory and evidence from IT projects. Decision Sciences, 38(1), 151-187. doi.org/10.1111/j.15405915.2007.00152.x

Tversky, A., \& Kahneman, D. (1974). Judgment under uncertainty: Heuristics and biases. Science, 185(4157), 11241131. doi:10.1126/science.185.4157.1124

Wang, P. (1996). Heuristics and normative models of judgment under uncertainty. International Journal of Approximate Reasoning, 14(4), 221-235. doi.org/10.1016/0888613X(95)00091-T

Zlatanović, D., \& Nikolić, J. (2017). Strategic decision making from the viewpoint of systems thinking: The role of values and context. In Z. Nedelko, \& M. Brzozowski (Eds.). Exploring the influence of personal values and cultures in the workplace (pp. 98-118). Hershey: Business Science Reference, doi:10.4018/978-1-5225-2480-9.ch006

Zlatanović, D. (2010). Strukturiranje upravljačkih problemskih situacija Metodologijom soft sistema. Ekonomski horizonti, 12(2), 95-112.

$$
\begin{array}{r}
\text { Received on } 20^{\text {th }} \text { March } 2018, \\
\text { after revision, } \\
\text { accepted for publication on } 23^{\text {rd }} \text { April } 2018 . \\
\text { Published online on } 26^{\text {th }} \text { April } 2018 .
\end{array}
$$

Jelena Nikolic is an Assistant Professor at the Faculty of Economics, University of Kragujevac, where she received her PhD degree. She teaches the courses of Introduction to Management, Decision-making Theory and Corporate Governance. She focuses her research interest on strategic decision-making, corporate governance and corporate entrepreneurship 


\title{
PREDRASUDE U PROCESU ODLUČIVANJA I MOGUĆNOSTI NJIHOVOG PREVAZILAŽENJA
}

\author{
Jelena Nikolic* \\ Ekonomski fakultet Univerziteta u Kragujevcu
}

Polazeći od normativnog pristupa, odluka kao ishod procesa odlučivanja treba da predstavlja racionalan izbor od strane potpuno informisanog donosioca odluka. Sa razvojem biheviorističke perspektive u analizi procesa odlučivanja, uočene su određene greške u ponašanju donosilaca odluka, koje nastaju kao posledica njihovih ograničenih kognitivnih kapaciteta i informacione asimetrije. Primena heuristika kao pojednostavljenih mentalnih strategija, kao i određene deformacije u razmišljanju i percepciji donosilaca odluka, dovode do različitih predrasuda koje utiču na njihove stavove i pristup procesu rešavanja problema. Svrha istraživanja ogleda se u identifikovanju predrasuda koje se najčešće pojavljuju u procesu odlučivanja, kao i njihovih uzroka i posledica. Primenjena je kvalitativna metodologija istraživanja i relevantni metodi analize i sinteze, dedukcija i indukcija. Na osnovu analize sprovedenih empirijskih studija, definisane su preporuke za prevazilaženje identifikovanih predrasuda, što predstavlja glavni rezultat istraživanja. Izvedeni zaključci o mogućnostima prevazilaženja predrasuda mogu pomoći donosiocima odluka da unaprede proces odlučivanja u realnim situacijama.

Ključne reči: proces odlučivanja, donosioci odluka, ograničena racionalnost, mentalne strategije, predrasude

JEL Classification: M10, D81

\section{UVOD}

U uslovima neizvesnosti, donošenje dobrih odluka postaje ključni faktor uspeha preduzeća. Proces odlučivanja predstavlja skup aktivnosti koje dovode do konačnog izbora jedne iz skupa mogućih akcija kojima će se ostvariti željeni cilj (Babić, 1995, 14). Polazeći od pretpostavke da su donosioci odluka

* Korespondencija: J. Nikolić, Ekonomski fakultet Univerziteta u Kragujevcu, Đ. Pucara 3, 34000 Kragujevac, Republika Srbija; e-mail: jnikolic@kg.ac.rs potpuno informisana i savršeno racionalna bića, razvoj normativnih modela odlučivanja predstavlja odgovor na uočenu potrebu da se propišu procedure odlučivanja koje će omogućiti racionalan izbor. Međutim, uočeno je da u realnim situacijama postoje odstupanja u primeni racionalnih procedura odlučivanja, kao i da je ponašanje donosilaca odluka pod uticajem nekontrolisanih faktora koji narušavaju uslove potpune informisanosti i racionalnosti.

Zapravo, istraživanje procesa odlučivanja $u$ realnim situacijama ukazuje na značaj razumevanja 
ograničenih kognitivnih kapaciteta donosilaca odluka koji dovode do grešaka u perspektivi posmatranja problema i negativno utiču na efektivnost odlučivanja (Maitland \& Sammartino, 2015). Kao posledica limitiranosti kognitivnih kapaciteta, donosioci odluka primenjuju različite heuristike kao mentalne strategije kojima pojednostavljuju probleme i redefinišu način njihovog rešavanja (Tiwana, Wang, Keil \& Ahluwalia, 2007). Uvođenjem koncepta ograničene racionalnosti (Simon, 1955), istraživanja u oblasti strategijskog odlučivanja su bila usmerena na izučavanje kognitivnih sposobnosti donosilaca odluka i njihovih granica, kao i na razumevanje ponašanja donosilaca odluka i mehanizama prevazilaženja uočene limitiranosti u procesu rešavanja kompleksnih problema (Menon, 2018). Shodno navedenom, razumevanje mentalnih strategija, kao mehanizama pojednostavljenja procesa odlučivanja, predstavlja prvi korak u suočavanju sa kompleksnim problemima (Levinthal, 2011).

Polazeći od shvatanja da su donosioci odluka ograničeno racionalni pojedinci, predmet istraživanja u radu su predrasude kao heuristike koje utiču na rasuđivanje donosilaca odluka i prouzrokuju određene sistemske greške $u$ procesu odlučivanja. Razumevanje predrasuda, koje nastaju kao posledica uticaja različitih sociopsiholoških faktora na donosioce odluka, predstavlja aktuelno istraživačko područje u oblasti teorije odlučivanja.

U datom kontekstu, cilj istraživanja u radu je da se pokaže na koji način predrasude utiču na ishode procesa odlučivanja i koji su mogući načini njihovog prevazilaženja.

Shodno definisanom predmetu i cilju istraživanja, polazna istraživačka hipoteza je da primena heuristika kao mentalnih strategija kojima se pojednostavljuje proces odlučivanja negativno utiče na kvalitet odluke kao ishod procesa odlučivanja.

Shodno navedenom, $\mathrm{u}$ radu se polazi od rezultata empirijskih istraživanja različitih autora koji su se bavili uticajem predrasuda na proces odlučivanja.

$\mathrm{Na}$ osnovu pregleda relevantnih istraživanja koji obuhvataju parcijalna izučavanja pojedinih predrasuda, sveobuhvatna analiza identifikovanih predrasuda u procesu odlučivanja predstavlja pokušaj da se odgovori na uočen istraživački gep. Primenjena je kvalitativna metodologija istraživanja, zasnovana na deskriptivnom proučavanju i interpretaciji rezultata sprovedene analize. U cilju izvođenja generalnih stavova u pogledu uzroka i posledica predrasuda na kvalitet procesa odlučivanja, primenjeni su metodi analize i sinteze, dedukcije i indukcije, kao odgovarajući istraživački metodi teorijske verifikacije postavljene hipoteze.

Rad je strukturiran u tri međusobno povezane celine. U prvom delu rada, analizirana je priroda procesa odlučivanja i ograničena racionalnost donosioca odluka. Polazeći od biheviorističke perspektive, posebna pažnja je posvećena istraživanju direktnih i indirektnih efekata ograničene racionalnosti u odlučivanju. Drugi deo rada je posvećen istraživanju predrasuda koje nastaju kao posledica ograničenih kognitivnih kapaciteta donosilaca odluka. Analizirane predrasude determinišu način na koji donosioci odluka prerađuju informacije $\mathrm{u}$ toku procesa odlučivanja, procenjuju ponuđene alternative i vrše izbor. $\mathrm{Na}$ osnovu sveobuhvatnog pregleda empirijskih istraživanja o predrasudama, $\mathrm{u}$ trećem delu rada posebna pažnja je posvećena identifikovanju mogućnosti njihovog prevazilaženja u cilju unapređenja kvaliteta procesa odlučivanja.

\section{OGRANIČENA RACIONALNOST U ODLUČIVANJU}

Iako postoje različiti pristupi u pojmovnom definisanju procesa odlučivanja, njihova zajednička odlika je da proces odlučivanja podrazumeva sve aktivnosti izbora jedne između ponuđenih opcija koje uključuju identifikovanje probema, generiranje i izbor alternative (Zlatanović \& Nikolić, 2017). U širem smislu, odlučivanje se posmatra kao skup aktivnosti koje se koriste da bi se pronašao i primenio onaj pravac delovanja koji će dovesti do ostvarenja postavljenog cilja. U užem smislu, odlučivanje predstavlja izbor jedne iz skupa razmatranih opcija (Babić, 1995, 15). Suština procesa odlučivanja jeste 
izbor najbolje odluke. Dobra odluka mora da zadovolji dva osnovna kriterijuma: efektivnost i efikasnost. Efektivna odluka je ona koja vodi ka potpunom ispunjenju postavljenog cilja, a efikasna odluka je ona koja sve akcije usmerene ka datom cilju oblikuje tako da se koristi minimum raspoloživih resursa (Howard \& Abbas, 2016, 30). Dobra odluka nastaje kao rezultat pravilnog razumevanja problema i definisanja ciljeva, kreativnog razvoja alternativa, objektivne evaluacije alternativa i konzistentnog izbora (Harrison, 1996). U cilju definisanja postupaka koji će dovesti do donošenja dobre odluke, razvijeni su normativni modeli odlučivanja.

Prema normativnim modelima racionalnog izbora, donošenje odluka se može okarakterisati kao racionalan, predvidiv i deterministički proces. Ponašanje donosilaca odluka u okviru navedenih aktivnosti, koje obuhvata proces odlučivanja, odlikuje potpuna racionalnost i izbor optimalnog rešenja. Problemi koji se rešavaju su dobro strukturirani, a izbor je konzistentan (Simon, 1959). Navedene karakteristike proizilaze iz shvatanja da su donosioci odluka, kao akteri procesa odlučivanja, idealno racionalni pojedinci koji, na osnovu racionalnih procedura i pravila odlučivanja, sprovode komparativnu evaluaciju aternativa i vrše izbor optimalne alternative (Sklad \& Diekstra, 2014). Zapravo, prema ekonomskoj teoriji firme kao predstavniku normativne perspektive izučavanja procesa odlučivanja, ponašanje donosilaca odluka predstavlja eksplicitni izbor zasnovan na logičkim, deduktivnim zaključcima, pri čemu se potpuno zanemaruju sva ograničenja koja proizilaze iz ljudske prirode. Donosioci odluka na osnovu potpunih informacija vrše proračun očekivane korisnosti opcija u zavisnosti od procenjenih verovatnoća relevantnih događaja i korisnosti svih mogućih ishoda analiziranih opcija (Wang, 1996). Potpuno informisan i racionalan donosilac odluke bira opciju koja maksimizira očekivanu korisnost (Levinthal, 2011).

Međutim, suprotno teorijskim pretpostavkama normativnog pristupa, potpuna racionalnost je nedostižna iz sledećih razloga: prvo, u slučaju većine odluka, lista potencijalnih posledica svake opcije je veoma duga, sa mnogim nepoznatim ishodima, što znači da ideja o potpunoj informisanosti nije realna; drugo, verovatnoće različitih ishoda obično nisu poznate i $\mathrm{u}$ najboljem slučaju mogu biti samo grubo procenjene, čime se dovodi u pitanje sposobnost donosioca odluka da izvrši racionalan izbor; treće, donosioci odluka se ne ponašaju uvek u skladu sa principom maksimiziranja. Ovakva vrsta razmišljanja koja podrazumeva optimizaciju ne može da reši kompleksne društvene probleme zato što ignoriše različite percepcije, vrednosti i interese koje postoje u organizacijama (Zlatanović, 2010). Polazeći od uočenih ograničenja normativnog pristupa, perspektiva $\mathrm{u}$ izučavanju procesa odlučivanja je promenjena. Racionalnost donosioca odluka se posmatra kroz prizmu međuzavisnosti objektivnog, racionalnog ponašanja i ponašanja koje je uslovljeno biheviorističkim faktorima koji oblikuju percepciju i rasuđivanje donosilaca odluka (Zlatanović \& Nikolić, 2017). Sa razvojem biheviorističke teorije, uočeno je da u realnim situacijama ponašanje donosilaca odluka odlikuje ograničena racionalnost, jer su njihovi kapaciteti limitirani u odnosu na problem koji se rešava (Simon, 1959).

Zapravo, bihevioristička perspektiva dovodi do shvatanja da se ponašanje aktera procesa odlučivanja u realnim situacijama često znatno razlikuje od racionalnog izbora i bazira na primeni jednostavnih pravila odlučivanja. Ovakvi zaključci su doveli do pretpostavke o ograničenoj racionalnosti donosilaca odluka, koja nastaje kao posledica problema informacione asimetrije i ograničenih kognitivnih kapaciteta aktera procesa odlučivanja. H. Simon (1955), kao utemeljivač koncepta ograničene racionalnosti, je opisao ograničenja koja proizilaze iz ljudske prirode i nemogućnosti racionalnog donošenja odluka. Navedeno znači da je kvalitet odluka determinisan stepenom u kome su kognitivne sposobnosti donosioca odluka ograničene (Huber, 1980, 25). Ovakav stav proizilazi iz shvatanja da donosilac odluka može da razmatra samo ograničen broj informacija $\mathrm{u}$ jednom trenutku; da mora da donese odluku u ograničenom vremenskom periodu, kao i da donosilac odluke ne može da poseduje sve relevantne informacije. U navedenom kontekstu, donosioci odluka teže da pronađu zadovoljavajuća, 
a ne optimalna rešenja (Simon, 1959). Polazeći od koncepta ograničene racionalnosti, može se zaključiti da donosioci odluka deluju na osnovu pojednostavljenih mentalnih modela koji se oblikuju pod uticajem ličnih stavova, percepcija i predrasuda. Zapravo, istraživanje procesa odlučivanja u realnim situacijama podrazumeva otkrivanje različitih percepcija, ili shvatanja sveta, kao i načina na koji se ove percepcije menjaju tokom vremena i razlikuju između aktera procesa odlučivanja (Zlatanović, 2010). To znači da dvosmislenost, nekonzistentnost i neizvesnost postaju ključne karakteristike procesa odlučivanja, što dovodi do potvrđivanja pretpostavke o ograničenoj racionalnosti donosilaca odluka.

U cilju prevazilaženja limitiranosti kognitivnih kapaciteta, donosioci odluka često pojednostavljuju donošenje odluka oslanjajući se na primenu heuristika (De Neys, 2010). U mnogim slučajevima, ove "mentalne prečice" dovode do približne aproksimacije u odnosu na optimalno rešenje (Pavličić, 2015, 301). Shodno navedenom, jedan od direktih efekata ograničene racionalnosti se odnosi na stav da donosioci odluka u realnim situacijama ne vrše optimalan izbor (Campitelli \& Gobet, 2010). Oni, zapravo, koriste jednostavne procedure i pravila odlučivanja. Jedno od takvih pravila je izbor zadovoljavajuće alternative, što znači da se bira alternativa koja zadovoljava zahteve donosioca odluke, dok se samo u izuzetnim slučajevima donosioci odluka opredeljuju na traženje i selekciju optimalne alternative (March, 1994, 18). Takođe, kao posledica ograničene racionalnosti, donosioci odluka često čine samo minimum inkrementalnog prilagođavanja neophodnog da bi problem sveli na takav nivo gde je razlika između željenih i postojećih ciljeva prihvatljiva. Ovakav pristup može da bude efikasan na kratak rok, ali dugoročno posmatrano ovakvo ponašanje može da izazove neželjene posledice.

Drugi direktan efekat ograničene racionalnosti je primena neadekvatnih modela odlučivanja. To znači da donosioci odluka, usled ograničenih kognitivnih kapaciteta, koriste aproksimativan, pojednostavljen model realne situacije (Bresnick \& Parnell, 2013, 33). Primena ovakvih modela pomaže donosiocima odluka da rešavaju kompleksne probleme kroz primenu različitih "mentalnih prečica" koje omogućavaju njihovo pojednostavljenje (Levinthal, 2011; Menon, 2018). Modeli odlučivanja zasnovani na heuristici su manje efikasni od optimizacionih modela, čija primena u rešavanju problema podrazumeva prikupljanje svih relevantnih informacija, kao i matematičku specifikaciju alternativa. Suprotno, primena heuristike se zasniva na "ignorisanju informacija" u cilju bržeg i jednostavnijeg odlučivanja, $\mathrm{u}$ odnosu na primenu metoda optimizacije (Maitland \& Sammartino, 2015). Primena jednostavnih pravila i neadekvatnih modela odlučivanja, kao direktne posledice fenomena ograničene racionalnosti donosilaca odluka dovodi do opadanja kvaliteta odluke.

Navedene posledice ograničene racionalnosti se mogu povezati sa određenim psihološkim faktorima koji utiču na donosioce odluke u procesu prikupljanja i analize informacija relevantnih za proces odlučivanja. Psihološki faktori poput neosnovane samouverenosti donosioca odluka, preteranog vezivanja za početne informacije, povezivanje alternativa sa stereotipima, davanje podrške pogrešnim izborima, zavisnost od forme prikazivanja problema mogu, u velikoj meri, da oblikuju percepciju donosilaca odluka u procesu odlučivanja i konačan ishod (Bresnick \& Parnell, 2013, 35). Reč je o predrasudama koje nastaju kao posledica kognitivne limitiranosti donosioca odluka, a prouzrokuju filtrirano prikupljanje i subjektivnu evaluaciju informacija $\mathrm{u}$ korist onih koje potvrđuju njihov stav o određenom problemu, a ignorišu informacije suprotne njihovom mišljenju. Shodno navedenom, uticaj informacione asimetrije dovodi do informacionih barijera koje prouzrokuju filtrirano prikupljanje informacija. Pod uticajem informacionih barijera, donosioci odluka formiraju lične preferencije koje mogu dovesti do distorzije $\mathrm{u}$ analizi informacija (Jamieson \& Hyland, 2006). Takođe, količina informacija dostupnih donosiocima odluka često premašuje njihove kognitivne sposobnosti potrebne za obradu informacija. Usled kognitivnih ograničenja, donosioci odluka nisu u stanju da obrade sve relevantne informacije, već pod uticajem predrasuda kao mentalnih prečica do rešenja problema dolaze pojednostavljenjem procesa donošenja odluka. U navedenom kontekstu, donosioci odluka vrše izbor 
zasnovan na primeni pojednostavljenih pravila i neadekvatnih modela odlučivanja, što negativno utiče na ishod procesa odlučivanja (Slika 1).

\section{PREDRASUDE KAO BIHEVIORISTIČKI ASPEKTI PROCESA ODLUČIVANJA}

U cilju otkrivanja uzroka i posledica predrasuda, koje nastaju pod uticajem određenih mentalnih grešaka, pojedini autori već više od dve decenije sprovode istraživanja u ovoj oblasti. Izvođenje generalnih zaključaka nije jednostavan proces, jer je potrebno sagledati ne samo ekonomsku, već i psihološku dimenziju određenih fenomena i pojava, kao i lične karakteristike donosilaca odluka koje mogu da utiču na njihovo ponašanje. Polazeći od brojnih empirijskih studija u ovoj oblasti (Tversky \& Kahneman, 1974; Kahneman \& Tversky, 1979; Chi \& Fan, 1997; Busenitz \& Barney, 1997; Hodgkinson, Maule, Bown, Pearman \& Glaister, 2002; Roxburg, 2003; Korte, 2003; Maqsood Finegan \& Walker, 2008; Forbes, 2005; Hammond, Keeney \& Raiffa, 2006; Jamieson \& Hyland, 2006; Chira, Adams \& Thornton, 2008; Henman, 2008;
McKenzie, van Winkelen \& Grewal, 2011; Bresnick \& Parnell, 2013; Sklad \& Diekstra, 2014; Riaz \& Iqbal, 2015; Fiedler \& von Sydow, 2015; Howard \& Abbas, 2016; Mustilli, Piccolo \& D’Angelo, 2018), u radu su identifikovani: uokviravanje problema, raspoloživost, reprezentativnost, efekat sidra i prilagođavanje, status quo, efekat potonulih troškova, potvrđivanje, lažni konsenzus, neosnovani optimizam i iluzija kontrole, kao najčešce predrasude koje oblikuju ishod procesa odlučivanja.

\section{Uokviravanje problema}

Prvi korak u procesu donošenja odluka je formulisanje problema koji treba rešiti. Postupak na koji donosioci odluka identifikuju problem može biti pod uticajem načina na koji se "problem uokviruje" (Henman, 2008; Pavličić, 2015, 314; Howard \& Abbas, 2016, 357). Najčešća prepreka objektivnom uočavanju i pravilnoj dijagnozi problema, kao osnovim koracima u fazi identifikacije problema je oblikovanje percepcije donosioca odluka u zavisnosti od načina na koji su informacije prikazane (Bresnick \& Parnell, 2013, 36). Ovaj efekat poznat je i kao aksiom invarijantnosti, prema kome, redefinisanje problema neće uticati na

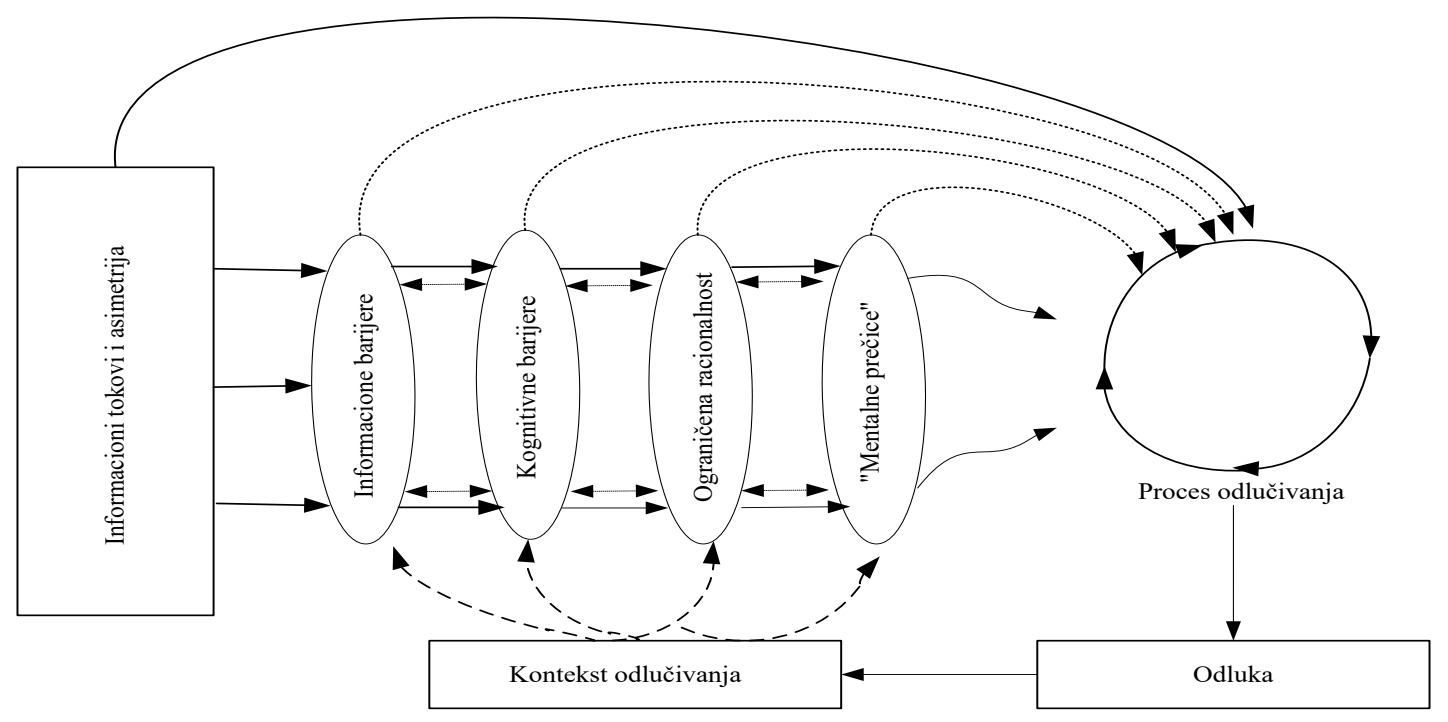

Slika 1 Ograničena racionalnost u odlučivanju

Izvor: Autor, prema Jamieson \& Hyland, 2006 
rezultate izbora, što znači da su preferencije donosioca odluka nezavisne od načina opisivanja problema (Tversky \& Kahneman, 1974). Međutim, aksiom invarijantnosti je često osporavan, jer su preferencije promenljive, a prilikom poređenja alternativa često dolazi do variranja atributa koji se razmatraju, što zajedno utiče na pojavu intranzitivnosti preferencija. U praksi je potvrđeno da donosioci odluka preferiraju pozitivan $\mathrm{u}$ odnosu na negativan okvir formulacije problema, kao i da sa promenom načina interpretacije informacija menjaju svoj stav (Tversky \& Kahneman, 1974; Kahneman \& Tversky, 1979; Jamieson \& Hyland, 2006; Hammond et al, 2006; Chira, Adams \& Thornton, 2008; McKenzie et al, 2011; Bresnick \& Parnell, 2013, 36). Promenom okvira u kome su prikazani mogući ishodi menja se i referentna tačka, što dovodi do oblikovanja preferencija donosilaca odluka i njihovog odnosa prema riziku (Božović \& Gvozdenović, 2009). Uočena averzija prema gubicima se odnosi na veću sklonost donosilaca odluka da izbegnu gubitak nego da ostvare dobitak (Tverski \& Kahneman, 1979). Sklonost ka rizičnim odlukama će, takođe, biti više izražena kada je problem "negativno uokviren". A. Tverski i D. Kahneman (1974) prvi potvrđuju da se gubici emocionalno doživljavaju dvostruko snažnije u poređenju sa uporedivim dobicima, što može da iskrivi percepciju donosilaca odluka $u$ fazi identifikacije problema.

\section{Raspoloživost}

Pod uticajem predrasude raspoloživosti, donosioci odluka verovatnoću jednog događaja procenjuju $\mathrm{u}$ zavisnosti od sopstvene memorije, odnosno, $\mathrm{u}$ zavisnosti od toga u kojoj meri se mogu setiti sličnih događaja (Hammond et al, 2006; Sklad \& Diekstra, 2013). Ukoliko se isti, ili slični događaj češće javljao u prošlosti, donosioci odluka mogu lakše da zamisle njegovu pojavu, dok se retkih događaja teže sećaju. Posledično, događaju koji češće nastaje pripisuje se visoka verovatnoća javljanja, dok se događaju koji se retko pojavljivao $\mathrm{u}$ prošlosti pripisuje niska verovatnoća javljanja (Pavličić, 2015, 301). Posledica ovakve percepcije je iskrivljeno mišljenje donosioca odluka i neobjektivna procena verovatnoće događaja, usled čega mogu da naprave pogrešne izbore (Korte,
2003). Procena verovatnoće budućih događaja, kao i rizika, više zavisi od memorije donosilaca odluka, nego od objektivne evaluacije mogućih događaja (Fiedler \& Sydow, 2015). Donosioci odluka predviđaju učestalost nekog događaja u zavisnosti od informacija koje su dostupne u njihovoj memoriji i koje oblikuju njihovo rasuđivanje i dovode do selektivne percepcije (Maqsood et al, 2008; Hammond et al, 2006; Henman, 2008; Bresnick \& Parnell, 2013, 37). Navedeno znači da donosioci odluka pogrešno procenjuju i predviđaju verovatnoće budućih događaja od kojih zavisi ishod odlučivanja, pod uticajem selektivnog pamćenja prošlih događaja (Howard \& Abbas, 2016, 351).

\section{Reprezentativnost}

Reprezentatitvnost predstavlja primenu mentalnih prečica u određivanju uslovnih verovatnoća, na osnovu procene $\mathrm{u}$ kojoj meri je neki događaj rezultat određenog procesa, odnosno, u kojoj meri određeni proces generiše analizirani događaj (Maqsood et al, 2008; Sklad \& Diekstra, 2013; Fiedler \& von Sydow, 2015). Zapravo, reč je o proceni verovatnoća uslovnih događaja zasnovanoj često na netačnoj sličnosti i povezanosti određenih događaja i pojava (Howard \& Abbas, 2016, 352). Reprezentativnost su prvi put opisali A. Tverski i D. Kahneman (1974), kao jednu od najčešćih predrasuda. Ovi autori su ukazali na pojavu da donosioci odluka pokazuju sklonost da u određenim situacijama generalizuju zaključke o posmatranom fenomenu, na osnovu analize samo nekoliko atributa, ili selektivnih zapažanja o određenoj pojavi. Određene studije, koje su se bavile ispitivanjem uticaja reprezentativnosti, pokazale su da su donosioci odluka skloni da ignorišu bazne informacije o određenoj pojavi (Chi \& Fan, 1997). Donosioci odluka potcenjuju mogućnost greške kod ovakvih procena, kao i nepouzdanost inherentnu malim uzorcima podataka. Zapravo, poseban oblik reprezentativnosti odnosi se na spremnost donosilaca odluka da generalizuju stavove na osnovu ispitivanja zasnovanih na malim uzorcima, ili na osnovu ličnog iskustva (Busenitz \& Barney, 1997). 


\section{Efekat sidra i prilagođavanje}

Predrasuda u teoriji poznata kao "efekat sidra" odnosi se na oblikovanje percepcije donosilaca odluka u zavisnosti od raspoloživih informacija i inicijalnog stava (Maqsood et al, 2008; Howard \& Abbas, 2016, 355). Inicijalne procene donosilaca odluka imaju veću specifičnu težinu u odnosu na kasnije prikupljene informacije, zbog čega postaju pristrasni u rasuđivanju (Hammond et al, 2006; Henman, 2008; McKenzie et al, 2011; Sklad \& Diekstra, 2014; Pavličić, 2015, 302). To znači da se polazi od jedne izabrane vrednosti koja predstavlja tzv. sidro, koja se zatim koriguje u zavisnosti od ostalih relevantnih faktora. Proces prilagođavanja je najčešce takav da rasuđivanje donosilaca odluka zavisi od inicijalnog sidra (Fiedler \& von Sydow, 2015). Sidra mogu imati različite forme. Jedan od najčešćih tipova sidra je prošli događaj ili trend (Hammond et al, 2006, 119). Stari podaci postaju sidra koje donosioci odluka koriguju, pri čemu se zanemaruje potreba za objektivnim prilagođavanjem novoj situaciji (Bresnick \& Parnell, 2013, 37). U uslovima koje karakterišu brze promene na tržištu, primena sidra dovodi do loših predviđanja i pogrešnih izbora (Roxburg, 2003).

\section{Status quo}

Donosioci odluka pokazuju jaku pristrasnost ka alternativama koje podržavaju status quo, naročito u situacijama kada je potrebno sprovesti promene (McKenzie et al, 2011). Donosioci odluka preferiraju status quo stanje kao manje rizičnu alternativu, zbog čega se često izbegava preduzimanje akcija čija bi implementacija narušila takvo stanje (Samuelson \& Zeckhauser, 1988; Hammond et al, 2006; Henman, 2008). Promena stanja status quo znači preduzimanje akcije, a samim tim i preuzimanje odgovornosti i posledica koje nastaju kao rezultat sprovedene akcije (Maitland \& Sammartino, 2015). Održavanje status quo stanja predstavlja, u većini slučajeva, lakši put u rešavanju problema, jer podrazumeva manji rizik, zbog čega donosioci odluka najčešće traže razloge kojima mogu da opravdaju takvo ponašanje (Bresnick \& Parnell, 2013, 37). To ipak ne znači da je izbor status quo stanja uvek pogrešan. Pravi izazov za donosioce odluka je da naprave razliku između opcije status quo koja je $\mathrm{u}$ određenom trenutku racionalan izbor i status quo opcije koja je rezultat averzije prema riziku i promenama (Roxburg, 2003).

\section{Efekat "potonulih troškova"}

Efekat potonulih, odnosno, neopravdanih troškova predstavlja posledicu uočenog fenomena da donosioci odluka često pokušavaju da novim izborima opravdaju ishode loših odluka u prošlosti (Roxburg, 2003; McKenzie et al, 2011; Pavličić, 2015, 315). To znači da dolazi do favorizovanja izbora one alternative koja podržava ranije donete odluke, čak i kada one nisu opravdane. Na taj način, prošle odluke postaju ono što se definiše kao potonuli troškovi, odnosno "stare investicije koje se ne mogu povratiti". Troškovi nastali kao posledica ranije donetih odluka su irelevantni za buduće odluke, a ipak determinišu proces odlučivanja i njegov ishod. Efekat potonulih troškova se dovodi u vezu sa fenomenom averzije prema riziku, što dovodi do odluka čija primena znači minimiziranje već izgubljenih resursa, a ne maksimiziranje očekivane korisnosti. Ovakav način donošenja odluka najčešće nastaje kada donosilac odluke mora da preuzme odgovornost za loš ishod. Drugim rečima, postoji značajna korelacija između preuzete odgovornosti i visine uloženih sredstava u određeni projekat (Chira et al, 2008). Do efekta potonulih troškova dolazi jer donosioci odluka svesno, ili nesvesno ne žele da priznaju sopstvenu grešku i preuzmu odgovornost (Hammond et al, 2006; Henman, 2008). Najčešće nastaje zajedno sa status quo efektom, ukoliko je status quo alternativa upravo ona u koju je donosilac odluke prekomerno investirao i želi da je opravda.

\section{Potreba za potvrđivanjem}

Potreba za potvrđivanjem podrazumeva traganje za informacijama koje podržavaju stav donosilaca odluka, dok se informacije koje ukazuju na moguće greške i loš ishod ignorišu (McKenzie et al, 2011). Ova predrasuda nastaje kao posledica tendencije donosilaca odluka da pronađu argumente kojima se potvrđuje uspostavljena dijagnoza problema, dok se argumenti protiv prihvatanja takvog stava odbacuju, čak iako su ubedljivi i racionalni (Pavličić, 
2015, 372). To znači da potreba za potvrđivanjem dovodi do pristrasnog izbora donosilaca odluka, koji se zasniva na nerealnom potvrđivanju prvobitnog stava ili već donetih odluka (Bresnick \& Parnell, 2013, 37). Ovaj efekat često nastaje kao posledica preterane samouverenosti donosilaca odluka $\mathrm{u}$ ispravnost odluke i nepogrešivost kada je u pitanju procena alternativa. Selektivna i pristrasna analiza sadržaja informacija kojima se podržava inicijalni stav je česta pojava u procesu odlučivanja (Jamieson \& Hyland, 2006; Hammond et al, 2006). Donosioci odluka prihvataju samo informacije koje opravdavaju ranije donete odluke, a odbacuju i/ili imaju kritičan i negativan stav prema informacijama koje bi mogle da dovedu u pitanje prethodne izbore (Chira et al, 2008).

\section{Lažni konsenzus}

Donosioci odluka subjektivno i pristrasno procenjuju stepen $\mathrm{u}$ kome njihovi saradnici slede i podržavaju njihove stavove i uverenja (Hammond et al, 2006). Ovakvo ponašanje je pozitivno jedino ako donosioci odluka vrše racionalan izbor. Istraživanja su pokazala da postoji mnogo faktora čije dejstvo prouzrokuje pomenuti efekat (Roxburg, 2003, 26): sklonost donosilaca odluka da prihvataju samo mišljenja i argumente koji podržavaju njihove stavove, ideje i predloge; selektivno sećanje, odnosno, navika da se pamte samo činjenice i iskustva kojima se pojačavaju prvobitne pretpostavke; pristrasna evaluacija, odnosno, brzo prihvatanje dokaza u korist postavljenih hipoteza, dok se kontradiktorni dokazi izlažu rigoroznoj evaluaciji i skoro izvesnom odbijanju; grupno mišljenje, odnosno, pritisak da se postigne visok stepen saglasnosti u jednoj grupi. Visoka kohezija podstiče pojavu grupnog mišljenja i može negativno da utiče na racionalnost $u$ rasuđivanju članova grupe kao donosilaca odluka, jer smanjuje njihovu sposobnost objektivnog sagledavanja problema pod uticajem mišljenja ostalih članova (Henman, 2008; Pavličić, 2015, 439).

\section{Neosnovani optimizam}

Neosnovani optimizam se povezuje sa visokim samopouzdanjem koje utiče na donosioce odluka kada procenjuju lične sposobnosti i granice znanja.
Donosioci odluka, kao ograničeno racionalni pojedinci, pod uticajem previsokog stepena samopouzdanja zasnovanog na stavu da su njihove sposobnosti izuzetne, imaju tendenciju da precenjuju svoju sposobnost donošenja dobrih odluka i donose ishitrene i nepromišljene odluke (Chira et al, 2008; Riaz \& Iqbal, 2015). Zapravo, kada donosioci odluka imaju nerealno visoko mišljenje o svojim sposobnostima i misle da znaju više nego što je to objektivno, najčešće donose loše odluke koje nastaju kao rezultat neobjektivno procenjenih verovatnoća i ishoda budućih događaja (Roxburg, 2003; Hammond et al, 2006). Neosnovani optimizam se odnosi na precenjivanje povoljnih $u$ odnosu na nepovoljne ishode bez uvažavanja i analize svih relevantnih informacija (Busenitz \& Barney, 1997; Jamieson \& Hyland, 2006; Chira et al, 2008). Procena verovatnoća događaja i predviđanje budućih ishoda nisu u potpunosti pouzdani, već su često rezultat neosnovanog optimizma koji se javlja kada donosioci odluka ili ne uočavaju opasnosti ili ih ignorišu (Golden, Milievicz \& Herbig, 1994). Ovaj efekat ima negativne posledice na razvoj i implementaciju dugoročnih strategija, jer većina njih bazira na nerealnim, optimističkim procenama budućih događaja (Roxburg, 2003; Henman, 2008). Ipak, iako se neosnovani optimizam može posmatrati kao široko rasprostranjena kognitivna pristrasnost, pojedina istraživanja su potvrdila da stepen samouverenosti i optimizma varira između pojedinaca i da može da se dovede u vezu sa ličnim karakteristikama donosioca odluka, poput pola, godina i obrazovanja (Simon \& Houghton, 2003; Forbes, 2005).

\section{Iluzija kontrole}

Iluzija kontrole nastaje kada donosioci odluka precenjuju stepen u kome su ishodi odluke pod njihovom ličnom kontrolom. Povezuje se sa precenjivanjem lične sposobnosti donosilaca odluke da uspešno rešavaju kompleksne probleme i donose efektivne odluke. Navedeni efekat se najčešće manifestuje kod donosilaca odluka koji su u prethodnom periodu donosili dobre odluke. Donosioci odluka se često nalaze pod uticajem iluzije kontrole, jer pažnju posvećuju analizi onih faktora koji su pod njihovom kontrolom, dok zanemaruju 
nekontrolisane faktore koji mogu da utiču na konačan izbor (Jamieson \& Hyland, 2006; Henman, 2008). Iluzija kontrole se može shvatiti kao tendencija pojedinaca da nerealno veruju da mogu da kontrolišu i/ili utiču na ishode u situacijama koje su izvan njihove kontrole. Navedena predrasuda navodi donosioce odluka da veruju da na ishod mogu da utiču, čak i kada to nije moguće (Chira et al, 2008; Pavličić, 2015, 401). Ova predrasuda je povezana sa neosnovanom samouverenošču i optimizmom donosioca odluka, jer uticaj neosnovanog optimizma podstuče pojavu iluzije kontrole, odnosno, previsokog verovanja u lični uspeh, čak i kada je to suprotno objektivnim činjenicama (Riaz \& Iqbal, 2015).

\section{PREPORUKE ZA PREVAZILAŽENJE PREDRASUDA U PROCESU ODLUČIVANJA}

Na osnovu pregleda istraživanja uticaja predrasuda na proces odlučivanja, može se zaključiti da greške $\mathrm{u}$ individualnom odlučivanju nastaju zbog rutinskog rešavanja problema, nepravilne primene heuristika i različitih deformacija u razmišljanju koje izazivaju određeni psihološki faktori (Tabela 1). Polazeći od negativnih efekata analiziranih predrasuda, jedan od osnovnih istraživačkih izazova u oblasti strategijskog odlučivanja je istražiti mogućnosti njihovog prevazilaženja. Osnovna pretpostavka ublažavanja sistemskih grešaka, koje dovode do loših ishoda, je da donosioci odluka preduprede negativan uticaj predrasuda.

Pre svega, neophodno je da budu svesni uticaja predrasuda na sposobnost rasuđivanja i predviđanje budućih događaja, kao i da primenjuju kritički pristup u procesu odlučivanja. Na osnovu analize uzroka identifikovanih predrasuda, u radu su identifikovane mogućnosti njihovog prevazilaženja (Tabela 1). Prikupljanje i analiza svih relevantnih informacija od kojih zavisi ishod procesa odlučivanja, kao i povećanje svesti donosilaca odluka da njihove odluke mogu biti pogrešne, je polazna pretpostavka u procesu prevazilaženja identifikovanih predrasuda (Hodgkinson et al, 2002; Roxburg, 2003; Hammond et al, 2006).
U cilju prevazilaženja negativnog uticaja efekata uokviravanja problema, donosioci odluka treba da sagledaju problem iz različitih perspektiva, kako bi se uočili svi relevantni aspekti postavljenog problema. $\mathrm{O}$ načinu formulisanja, odnosno, prezentacije problema treba razmišljati u svim fazama procesa odlučivanja, a ne samo $\mathrm{u}$ fazi identifikovanja problema. U cilju pronalaženja novih alternativa za rešavanje problema, u završnoj fazi procesa odlučivanja je svrsishodno vratiti se na inicijalnu fazu identifikovanja problema i promeniti perspektivu posmatranja. Navedena preporuka je u skladu sa shvatanjem da „okvir poblema" određuje širinu konteksta u kome se problem posmatra i oblikuje izbor elemenata koji su značajni u analizi problema. Kako je odlučivanje cikličan proces, a ne skup linearnih aktivnosti, promena okvira problema može da utiče na tok odlučivanja.

Negativan uticaj raspoloživosti i reprezentativnosti se može smanjiti ukoliko donosioci odluka verovatnoću događaja određuju na osnovu objektivne analize relevantnih podataka, bez obzira na njihovu učestalost pojavljivanja u prošlosti. Osnovna pretpostavka ovakvog pristupa je posedovanje potrebnih znanja i veština, kao i racionalna analiza povezanih događaja i procesa nezavisno od prethodnog iskustva donosioca odluka. Zapravo, potrebno je pridavati manji značaj već prikupljenim informacijama u odnosu na potrebu za prikupljanjem novih informacija koje mogu da dovedu do promena $u$ predviđanju verovatnoće $i$ ishoda budućih događaja.

Jedan od načina eliminisanja efekta sidra je primena alternativnih pristupa $u$ procesu rešavanja problema koji se ne oslanjaju na prošla iskustva donosioca odluka. Donosioci odluka treba da budu otvoreni za nove ideje i predloge. Poželjno je da saslušaju različita mišljenja kako bi proširili prvobitne ideje i pristup istraživanju problema koji treba da dovede do najboljeg rešenja. Takođe, donosioci odluka treba da budu objektivni kada razmatraju predloge svojih saradnika i da im ne nameću sopstvene ideje kao moguća rešenja.

Izbor status quo opcije može u pojedinim situacijama da bude najbolje rešenje, ali to ne znači da ga treba 
Tabela 1 Pregled istraživanja o uticaju predrasuda na proces odlučivanja

\begin{tabular}{|c|c|c|}
\hline $\begin{array}{l}\text { ISTRAŽIVANJA } \\
\text { O PREDRASUDAMA }\end{array}$ & $\begin{array}{l}\text { ZNAČENJE } \\
\text { PREDRASUDE }\end{array}$ & PREPORUKE ZA PREVAZILAŽENJE \\
\hline \multicolumn{3}{|l|}{ Uokviravanje problema } \\
\hline $\begin{array}{l}\text { Tversky \& Kahneman, 1974; } \\
\text { Kahneman \& Tversky, 1979; } \\
\text { Hammond et al, 2006; } \\
\text { Henman, 2008; } \\
\text { Chira et al, 2008; } \\
\text { McKenzie et al, 2011; } \\
\text { Bresnick \& Parnell, 2013; } \\
\text { Howard \& Abbas, 2016 }\end{array}$ & $\begin{array}{l}\text { Preferencije donosioca odluka } \\
\text { zavise od načina prezentacije } \\
\text { problema. } \\
\text { Različiti pristupi u definisanju } \\
\text { problema dovode do promene } \\
\text { preferencija donosioca odluka. }\end{array}$ & $\begin{array}{l}\text { U inicijalnoj fazi procesa odlučivanja } \\
\text { problem treba posmatrati iz različitih } \\
\text { perspektiva. } \\
\text { U završnoj fazi izbora vratiti se na inicijalnu } \\
\text { fazu identifikovanja problema i promeniti } \\
\text { perspektivu fomulisanja problema u cilju } \\
\text { razvoja novih alternativa. }\end{array}$ \\
\hline
\end{tabular}

\section{Raspoloživost}

Tversky \& Kahneman, 1974;

Korte, 2003;

Preferencije donosioca odluka zavise od načina prezentacije problema.

Razliciti pristupi u definisanju preferencija donosioca odluka.
U inicijalnoj fazi procesa odlučivanja problem treba posmatrati iz različitih perspektiva.

U završnoj fazi izbora vratiti se na inicijalnu fazu identifikovanja problema i promeniti razvoja novih alternativa.
Hammond et al, 2006;

Henman, 2008;

Maqsood et al, 2008;

Bresnick \& Parnell, 2013;

Sklad \& Diekstra, 2014;

Fiedler \& von Sydow, 2015;

Howard \& Abbas, 2016

\section{Reprezentativnost}

Tversky \& Kahneman, 1974;

Chi \& Fan, 1997;

Busenitz \& Barney, 1997;

Maqsood et al, 2008;

Sklad \& Diekstra, 2014;

Fiedler \& von Sydow, 2015;

Howard \& Abbas, 2016

\section{Efekat sidra}

Roxburg, 2003;

Hammond et al, 2006;

Henman, 2008;

McKenzie et al, 2011;

Bresnick \& Parnell, 2013;

Sklad \& Diekstra, 2014;

Fiedler \& Sydow, 2015

Procena verovatnoće budućih događaja i njihovih ishoda više zavisi od memorije donosioca odluka, nego od objektivne evaluacije.
Oblikovanje percepcije donosioca odluka u zavisnosti od raspoloživih informacija i inicijalnog stava koji ima veću specifičnu težinu u odnosu na kasnije prikupljene informacije. kojoj meri određeni proces generiše događaj.

Određivanje uslovnih verovatnoća na osnovu subjektivne procene u kojoj meri je neki događaj rezultat određenog procesa, odnosno u
Predviđanje verovatnoće događaja na osnovu relevantnih informacija, bez obzira na njihovu učestalost pojavljivanja i prethodno iskustvo donosioca odluka. Manji značaj pridavati informacijama koje donosioci odluka već poseduju.

\section{Status quo}

Samuelson \& Zeckhauser, 1988;

Roxburg, 2003;

Hammond et al, 2006;

Henman, 2008;

McKenzie et al, 2011;

Bresnick \& Parnell, 2013;

Maitland \& Sammartino, 2015
Predviđanje verovatnoće uslovnih događaja na osnovu objektivne procene, a ne na osnovu subjektivnog zaključivanja. Ispitati uzročno-posledičnu povezanost uslovnih događaja.

\section{Efekat potonulih troškova}

Roxburg, 2003;

Hammond et al, 2006;

Chira at al, 2008;

Henman, 2008;

McKenzie et al, 2011
Pristrasnost donosioca odluka ka izboru alternativa koje podržavaju izbor status quo, kao manje rizične alternative.

Može se povezati sa averzijom

prema riziku i sprovođenju promena.
Sagledavanje problema iz različitih perspektiva i primena alternativnih pristupa.

Donosioci odluka treba da budu otvoreni za nove ideje i predloge koje mogu da utiču na promenu inicijalnog shvatanja.
Status quo ne treba posmatrati kao jedinu alternativu, već je poželjno razviti veći broj opcija i pažljijvo evaluirati njihove prednosti.

Preispitati da li je status quo zaista najbolja opcija i kada bi uključivala određeni rizik.
Donosioci odluka pokušavaju da novim izborima opravdaju ishode ranije donetih loših odluka favorizovanje izbora one alternative koja podržava ranije donete odluke.
Podsticati otvorenu kulturu koja ne izaziva strah od neuspeha i dovodi do toga da donosioci odluka priznaju svoje greške. Angažovati pojedince koji nisu bili uključeni u donošenje ranijih odluka. 


\begin{tabular}{|c|c|c|}
\hline Potvrđivanje & & \\
\hline $\begin{array}{l}\text { Hammond et al, 2006; } \\
\text { Jamieson \& Hyland, 2006; } \\
\text { Henman, 2008; } \\
\text { McKenzie et al, 2011; } \\
\text { Bresnick \& Parnell, } 2013\end{array}$ & $\begin{array}{l}\text { Pristrasno prikupljanje informacija } \\
\text { i izbor donosioca odluka, koji se } \\
\text { zasniva na nerealnom potvrđivanju } \\
\text { prvobitnog stava i ranije donetih } \\
\text { odluka. }\end{array}$ & $\begin{array}{l}\text { Proveriti da li su sve alternative ocenjene } \\
\text { na osnovu istih kriterijuma. } \\
\text { Ispitati argumente koji podržavaju } \\
\text { predloženu alternativu i podsticanje } \\
\text { kritičkog stava u izboru alternativa. }\end{array}$ \\
\hline \multicolumn{3}{|l|}{ Lažni konsenzus } \\
\hline $\begin{array}{l}\text { Roxburg, 2003; } \\
\text { Hammond et al, 2006; } \\
\text { Henman, } 2008\end{array}$ & $\begin{array}{l}\text { Donosioci odluka pristrasno } \\
\text { procenjuju stepen u kome njihovi } \\
\text { saradnici podržavaju njihove } \\
\text { stavove i uverenja. }\end{array}$ & $\begin{array}{l}\text { Stvaranje kulture koja podstiče } \\
\text { konstruktivni konflikt. } \\
\text { Podsticanje otvorene i konstruktivne } \\
\text { kritike. }\end{array}$ \\
\hline \multicolumn{3}{|l|}{ Neosnovani optimizam } \\
\hline $\begin{array}{l}\text { Golden et al, 1994; } \\
\text { Busenitz \& Barney, 1997; } \\
\text { Roxburg, 2003; } \\
\text { Simon \& Houghton, 2003; } \\
\text { Forbes, 2005; } \\
\text { Hammond et al, 2006; } \\
\text { Jamieson \& Hyland, 2006; } \\
\text { Henman, 2008; } \\
\text { Chira et al, 2008; } \\
\text { Riaz \& Iqbal, 2015 }\end{array}$ & $\begin{array}{l}\text { Donosioci odluka precenjuju } \\
\text { povoljne u odnosu na nepovoljne } \\
\text { ishode. Nastaje kada donosioci } \\
\text { odluka nerealno i previše } \\
\text { optimistično vrše predviđanje } \\
\text { budućih događaja bez analize svih } \\
\text { relevantnih informacija. }\end{array}$ & $\begin{array}{l}\text { Primena racionalnog pristupa u } \\
\text { predviđanju i proceni verovatnoća } \\
\text { događaja. } \\
\text { Preispitati objekivnost ličnih pretpostavki i } \\
\text { procene budućih ishoda. } \\
\text { Preispitati uzročno-posledične relacije } \\
\text { koje su često proizvod previsoke } \\
\text { samouverenosti donosioca odluka. }\end{array}$ \\
\hline \multicolumn{3}{|l|}{ Iluzija kontrole } \\
\hline $\begin{array}{l}\text { Jamieson \& Hyland, 2006; } \\
\text { Henman, 2008; } \\
\text { Chira et al, 2008; } \\
\text { Riaz \& Iqbal, 2015 }\end{array}$ & $\begin{array}{l}\text { Donosioci odluka precenjuju stepen } \\
\text { u kome su ishodi odluke pod } \\
\text { njihovom kontrolom. }\end{array}$ & $\begin{array}{l}\text { Podsticati donosioce odluka da budu } \\
\text { kritični u procenama ličnih sposobnosti i } \\
\text { moći koju poseduju. }\end{array}$ \\
\hline
\end{tabular}

Izvor: Autor

uvek slediti. Status quo ne treba posmatrati kao jedinu alternativu, već je neophodno da donosioci odluka identifikuju i analiziraju veći broj različitih opcija, pažljivo evaluirajući prednosti i nedostatke svake od njih. U situacijama kada donosioci odluka podržavaju status quo, treba da postave pitanje da li bi izabrali takvu alternativu kada bi ona podrazumevala određeni stepen rizika. Osim navedene preporuke, donosioci odluka treba da preispitaju postavljene ciljeve, kako bi objektino sagledali da li su zadovoljni postojećim stanjem, ili je potrebno da preduzmu određene promene, bez obzira na napor i troškove koje promene zahtevaju.

Odluke koje imaju određenu "istoriju" teško je posmatrati objektivno, jer na donosioce odluka utiču određeni psihološki faktori koji determinišu njihovu sposobnost rasuđivanja i način odlučivanja. U tom smislu, prevazilaženje efekta potonulih troškova zasniva se na uvažavanju mišljenja i predloga onih aktera procesa odlučivanja koji nisu bili uključeni u donošenje prethodnih odluka. Donosilac odluke treba da preispita razloge zbog kojih ne želi da prizna grešku i da snosi relevantne posledice. Najčešće, ključni razlog je narušen ugled i samopoštovanje donosioca odluka. U tom smislu, treba destimulisati kulturu koja izaziva strah od neuspeha i dovodi do toga da donosioci odluka ne žele da priznaju greške.

Uticaj potvrđivanja je moguće prevazići ukoliko su donosioci odluka spremni da kritički preispitaju ranije donete odluke. Pre svega, treba proveriti da li su sve alternative ocenjene na osnovu istih kriterijuma, a zatim ispitati argumente koji podržavaju predloženu alternativu. Donosilac odluke treba objektivno da analizira lične motive koji podržavaju donetu odluku. Preporuka je da donosilac odluke sagleda da li prikuplja informacije u cilju poboljšanja kvaliteta izbora, ili je njegov osnovni motiv da potvrdi izabrani pravac delovanja. Podsticanje kritičkog 
stava donosioca odluke je nužna pretpostavka prevazilaženja navedenog uticaja.

Najbolji način ublažavanja uticaja lažnog konsenzusa je stvaranje kulture koja podstiče kreativni konflikt. Akteri procesa odlučivanja treba da podstiču konstruktivnu kritiku, kao i nove kreativne predloge. Kritički pristup treba posmatrati kao koristan i poželjan, a ne kao "neprijateljski čin". Preporuka je da se za svaki argument u prilog izabrane opcije izloži i kontra argument u cilju sveobuhvatne i objektivne analize.

Jedna od preporuka u cilju prevazilaženja neosnovanog optimizma je primena racionalnog pristupa u predviđanju i proceni verovatnoća. Treba pažljivo ispitati sve pretpostavke donosilaca odluka i uporediti ih sa relevantnim podacima, kako bi se smanjio uticaj ličnih impresija. Preporuka za donosioce odluka je da u procesu filtriranja i analize prikupljenih informacija budu nepristrasni. Potrebno je preispitati uspostavljene uzročnoposledične relacije koje su često proizvod previsoke samouverenosti donosilaca odluka, kao i utemeljenost ličnih pretpostavki i stavova.

Polazeći od međusobne povezanosti neosnovanog optimizma i iluzije kontrole, preporučuje se sličan pristup u prevazilaženju negativnih posledica iluzije kontrole. Podsticanje kritičkog preispitivanja ličnih sposobnosti i moći, koju poseduju donosioci odluka, smatra se osnovnom pretpostavkom ublažavanja navedenih negativnih efekata iluzije kontrole koji mogu da prouzrokuju donošenje loše odluke.

\section{ZAKLJUČAK}

Uprkos nastojanju da u procesu donošenja odluka primene racionalne modele izbora, donosioci odluka često donose pogrešne odluke. Osnovni razlozi donošenja loših odluka su nedostatak posvećenosti i ograničena racionalnost donosilaca odluka. Efekti ograničene racionalnosti determinišu način na koji donosioci odluka vrše izbor. Različiti bihevioristički faktori, u zavisnosti od konteksta u kome se odluke donose, oblikuju način na koji donosioci odluka prikupljaju, filtriraju, prerađuju i analiziraju informacije $u$ procesu odlučivanja i vrše izbore. Navedeno znači da se donosioci odluka, zbog limitiranih kognitivnih kapaciteta, oslanjaju na pojednostavljeno rešavanje kompleksnih problema kroz primenu mentalnih prečica. Kognitivna ograničenja dovode do predvidivih i konzistentnih mentalnih grešaka prouzrokovanih pojednostavljenim prikupljanjem, analizom i obradom informacija. Neki od definisanih kognitivnih limita odnose se na formulisanje problema, neki na procenu verovatnoća relevantnih događaja, a neki nastaju i kao posledica pogrešne percepcije ličnih sposobnosti donosilaca odluka. Donosioci odluka problem posmatraju kroz prizmu subjektivnih mišljenja i uverenja, oslanjajući se na prethodne događaje i postojeće informacije.

Ovakvo razmišljanje upućuje na zaključak da greške $\mathrm{u}$ odlučivanju nastaju zbog rutinskog rešavanja problema, primene heuristika kao mentalnih prečica i različitih deformacija u razmišljanju koje izazivaju određeni psihološki faktori čime je potvrđena polazna hipoteza. Shodno navedenom, doprinos rada $\mathrm{u}$ teorijskom smislu se ogleda $\mathrm{u}$ identifikovanju različitih predrasuda i razumevanju njihovog uticaja na ishod procesa odlučivanja. U praktičnom smislu, definisane preporuke za ublažavanje negativnog uticaja predrasuda mogu pomoći donosiocima odluka da unaprede proces odlučivanja u realnim situacijama. Takođe, izvedeni zaključci predstavljaju dobru osnovu za sprovođenje istraživanja kojim bi se empirijski testirali uzroci i posledice analiziranih predrasuda. Ipak, osnovno ograničenje istraživanja ogleda se u izvođenju zaključaka na osnovu pregleda literature i sekundarnih podataka, bez sprovođenja originalnog empirijskog istraživanja. Shodno navedenom, pravci budućeg istraživanja su oslonjeni na razvoj istraživačkog modela zasnovanog na izvedenim zaključcima sprovedene kvalitativne analize uticaja identifikovanih predrasuda u cilju empirijske verifikacije postavljene hipoteze. 


\section{REFERENCE}

Babić, V. (1995). Strategijsko odlučivanje. Beograd, Republika Srbija: Institut za ekonomiku i finansije.

Božović, B., \& Gvozdenović, V. (2009). Nerealistični optimizam i donošenje odluka. Psihologija, 42(4), 567-584.

Bresnick, A. T., \& Parnell, S. G. (2013). Decision-making challenges. In S. G. Parnell, A. T. Bresnick, N. S. Tani, \& E.R. Jonson (Eds.). Handbook of Decision Analysis (pp. 22-46). New Jersey: John Wiley \& Sons

Busenitz, L., \& Barney, J. (1997). Differences between entrepreneurs and managers in large organizations: Biases and heuristics in strategic decision-making. Journal of Business Venturing, 12(1), 9-30. doi.org/10.1016/S08839026(96)00003-1

Campitelli, G., \& Gobet, F. (2010). Herbert Simon's decisionmaking approach: Investigation of cognitive processes in experts. Review of General Psychology, 14(4), 354-364. doi. org/10.1037/a0021256

Chi, T., \& Fan, D. (1997). Cognitive limitations and investment 'myopia'. Decision Sciences, 28(1), 27-57. doi. org/10.1111/j.1540-5915.1997.tb01301.x

Chira, I., Adams, M., \& Thornton, B. (2008). Behavioral bias within the decision making process. Journal of Business $\mathcal{E}$ Economics Research, 6(8), 11-20. doi:10.19030/jber.v6i8.2456

De Neys, W. (2010). Heuristic bias, conflict, and rationality in decision-making. In B. M. Glatzeder, V. Goel., \& A. Müller (Eds.). Towards a Theory of Thinking, On Thinking (pp. 22-33). Berlin: Springer, doi:10.1007/978-3-642-03129-8_2

Fiedler, K., \& von Sydow, M. (2015). Heuristics and biases: Beyond Tversky and Kahneman's (1974) judgment under uncertainty. In M. Eysenck \& D. Groome (Eds.). Revisiting the Classical Studies (pp. 146-161). Sage Publications, Retrieved March 9, 2018, from https://www.researchgate. net/publication/280981235_Heuristics_and_Biases_ Beyond_Tversky_and_Kahneman\%27s_1974_Judgment_ under_Uncertainty

Forbes, D. (2005). Are some entrepreneurs more overconfident than others? Journal of Business Venturing, 20(5), 623-640. doi. org/10.1016/j.jbusvent.2004.05.001

Golden, J., Miliwicz, J., \& Herbig, P. (1994). Forecasting: Trials and Tribulations. Management Decision, 32(1), 33-39.

Hammond, J., Keeney, R., \& Raiffa, H. (2006). The hidden traps in decision making. Harvard Business Review, 84(1), 118-127.
Harrison, F. (1996). A Process Perspective on Decision Making. Management Decision, 34(1), 46-53. doi. org/10.1108/00251749610106972

Henman, D. L. (2008). How to avoid the hidden traps of decision making. Retrieved March 9, 2018, from http://www. henmanperformancegroup.com/articles/Avoid-HiddenTraps.pdf

Hodgkinson, G., Maule, J., Bown, J., Pearman, A., \& Glaister, K. (2002). Further reflections on the elimination of framing bias in strategic decision making. Strategic Management Journal, 23(11), 1069-1076. doi:10.1002/smj.266

Howard, A.R., \& Abbas, E. A. (2016). Foundation of Decision Analysis. England: Pearson Education Limited

Huber, G. (1980). Managerial Decision Making. London, UK: Longman Higher Education

Jamieson, K., \& Hyland, P. (2006). Good intuition or fear and uncertainty: The effects of bias on information systems selection decisions. Informing Science: International Journal of an Emerging Transdiscipline, 9, 49-69. Retrieved March 5, 2018, from http://inform.nu/Articles/Vol9/v9p049-069Jamieson60. pdf

Kahneman, D., \& Tversky, A. (1979). Prospect theory: An analysis of decision under risk. Econometrica, 47(2), 263-291. doi:10.2307/1914185

Korte, F. R. (2003). Biases in Decision Making and Implications for Human Resource Development. Advances in Developing Human Resources, 5(4), 440-457. doi. org/10.1177/1523422303257287

Levinthal, D. (2011). A behavioral approach to strategy What's the alternative? Strategic Management Journal, 32(13), 1517-1523. doi:10.1002/smj.963

Maitland, E., \& Sammartino, A. (2015). Decision making and uncertainty: the role of heuristics and experience in assessing a politically hazardous environment. Strategic Management Journal, 36(10), 1554-1578. doi:10.1002/smj.2297

Maqsood, T., Finegan, A., \& Walker, D. (2008). Biases and heuristics in judgment and decision making: The dark side of tacit knowledge. Informing Science and Information Technology, 1, 295-301. doi: 10.28945/740

March, J. (1994). A Primer on Decision Making: How Decision Happen. New York, NY: A Free Press. 
McKenzie, J., van Winkelen, C., \& Grewal, S. (2011). Developing organisational decision making capability: a knowledge manager's guide. Journal of Knowledge Management, 15(3), 403-421. doi:10.1108/13673271111137402

Menon, A. (2018). Bringing cognition into strategic interactions: Strategic mental models and open questions. Strategic Management Journal, 39(1), 168-192. doi:10.1002/ smj. 2700

Mustilli, M., Piccolo, R., \& D’Angelo, E. (2018). Crosscountry differences in how behavioral biases affect decision - making in the bank industry: Evidence from Italy and Serbia. American Journal of Industrial and Business Management, 8, 239-249. Retrieved January 18, 2018, from https://doi.org/10.4236/ajibm.2018.82016

Pavličić, D. (2015). Teorija odlučivanja. Beograd, Republika Srbija: Ekonomski fakultet Univerziteta u Beogradu.

Riaz, T., \& Iqbal, H. (2015). Impact of overconfidence, illusion of control, self control and optimism bias on investors decision making: Evidence from developing markets. Research Journal of Finance and Accounting, 6(11), 110-116.

Roxburg, C. (2003). Hidden flaws in strategy. The McKinsey Quarterly, 27(2), 21-30. Retrieved January 28, 2018, from https://www.mckinsey.com/business-functions/strategyand-corporate-finance/our-insights/hidden-flaws-instrategy

Samuelson, W., \& Zeckhauser, R. (1988). Status quo bias in decision making. Journal of Risk and Ucertainty, 1(1), 7-59. Retrieved Retrieved March 6, 2018, from https://link. springer.com/journal/11166

Simon, H. (1955). A Behavioral Model of Rational Choice. The Quarterly Journal of Economics, 69(1), 99-118. doi:10.2307/1884852
Simon, H. (1959). Theories of Decision Making in Economics and Behavioral Science. American Economic Review, 49(3), 253-283.

Simon, M., \& Houghton, S. (2003). The relationship between overconfidence and the introduction of risky products: Evidence from a field study. The Academy of Management Journal, 46(2), 139-149. doi:10.2307/30040610

Sklad, M., \& Diekstra, R. (2014). The development of the heuristics and biases scale. Procedia - Social and Behavioral Sciences, 112, 710-718. doi:10.1016/j.sbspro.2014.01.1221

Tiwana, A., Wang, J., Keil, M., \& Ahluwalia, P. (2007). The bounded rationality bias in managerial valuation of real options: Theory and evidence from IT projects. Decision Sciences, 38(1), 151-187. doi.org/10.1111/j.15405915.2007.00152.x

Tversky, A., \& Kahneman, D. (1974). Judgment under uncertainty: Heuristics and biases. Science, 185(4157), 11241131. doi:10.1126/science.185.4157.1124

Wang, P. (1996). Heuristics and normative models of judgment under uncertainty. International Journal of Approximate Reasoning, 14(4), 221-235. doi.org/10.1016/0888613X(95)00091-T

Zlatanović, D., \& Nikolić, J. (2017). Strategic decision making from the viewpoint of systems thinking: The role of values and context. In Z. Nedelko, \& M. Brzozowski (Eds.). Exploring the influence of personal values and cultures in the workplace (pp. 98-118). Hershey: Business Science Reference, doi:10.4018/978-1-5225-2480-9.ch006

Zlatanović, D. (2010). Strukturiranje upravljačkih problemskih situacija Metodologijom soft sistema. Ekonomski horizonti, 12(2), 95-112.

Primljeno 20. marta 2018, nakon revizije, prihvaćeno za publikovanje 23. aprila 2018. Elektronska verzija objavljena 26. aprila 2018.

Jelena Nikolić je docent na Ekonomskom fakultetu Univerziteta u Kragujevcu, gde je doktorirala. Izvodi nastavu na nastavnim predmetima Uvod u menadžment, Teorija odlučivanja, Korporativno upravljanje i Teorija korporativnog upravljanja. Ključne oblasti njenog naučnoistraživačkog interesovanja su: strategijsko odlučivanje, korporativno upravljanje i korporativno preduzetništvo. 


\title{
BIASES IN THE DECISION-MAKING PROCESS AND POSSIBILITIES OF OVERCOMING THEM
}

\author{
Jelena Nikolic \\ Faculty of Economics, University of Kragujevac, Kragujevac, The Republic of Serbia
}

Starting from the normative approach, a decision as the outcome of the decision-making process should represent a rational choice made by a completely informed decision-maker. With the development of the behavioral perspective of the decision-making process, certain mistakes in decision-makers' behavior have been noticed, emerging as a consequence of their limited cognitive capacities and the information asymmetry. The application of heuristics as simplified mental strategies, as well as certain deformations in decision-makers' thinking and perception, leads to the different biases that affect their attitudes and approach to problem solving. The aim of the research study is reflected in identifying the biases that most often occur in the decision-making process, as well as their causes and consequences. The qualitative methodology of the research has been applied in parallel with the relevant methods of analysis and synthesis, deduction and induction. On the basis of the conducted empirical studies, the recommendations for overcoming biases have been defined, which represents the main result of the research study. The derived conclusions with respect to the possibilities of overcoming biases can help decision-makers to improve the decision-making process in real situations.

Keywords: decision-making process, decision-makers, bounded rationality, mental strategies, biases

JEL Classification: M10, D81 